Federal Reserve Bank of Minneapolis

Research Department

\title{
The Macroeconomics of War and Peace
}

\author{
R. Anton Braun and Ellen R. McGrattan*
}

Working Paper 511

Revised June 1993

*Braun, Federal Reserve Bank of Minneapolis and University of Virginia; McGrattan, Federal Reserve Bank of Minneapolis and Duke University. We wish to thank Rao Aiyagari, Olivier Blanchard, V.V. Chari, Bradford DeLong, Marty Eichenbaum, Jeff Eischen, Ed Green, Nobu Kiyotaki, Ed Prescott, Richard Rogerson, Julio Rotemberg, Warren Weber, and workshop participants at Northwestern, University of Iowa, University of Minnesota, and the Federal Reserve Bank of Minneapolis for helpful suggestions. The second author thanks the NSF and the North Carolina Supercomputing Center for their support. The views expressed herein are those of the authors and not necessarily those of the Federal Reserve Bank of Minneapolis or the Federal Reserve System. 


\section{Introduction}

This paper examines the effects of government purchases on economic activity. Among economists, there is a basic agreement about the effects of increased government purchases. A transient rise in government spending increases output, drives up interest rates but, crowds out private consumption and investment. There are a variety of theories that are consistent with these facts. Competitive models described by Hall [1980], Barro [1981] or Aiyagari, Christiano, and Eichenbaum [1992] predict these responses as do the imperfectly competitive models considered by Rotemberg and Woodford [1991,1992]. Other predictions of these competing explanations are at odds. Competitive models predict that the real wage should fall due to the negative wealth effect of higher tax liabilities. Imperfectly competitive models predict that real wages ought to rise.

Isolating the effects of government policy on gross national product and the labor market is generally difficult due to problems of simultaneity. But these problems may be resolved if the policy is sufficiently large to dominate other events. The two largest examples of government demand shocks in this century are the two World Wars. At the peak of World War I, U.S. military expenditures absorbed about 16 percent of GNP and military outlays in Great Britain absorbed close to 40 percent of GDP. World War II resulted in even higher expenditures with U.S. military outlays absorbing about 40 percent of GNP and British military expenditures absorbing about 50 percent of GDP. Events of this magnitude offer an interesting laboratory for establishing the facts about the effects of government purchases on economic activity and evaluating the plausibility of competing economic theories.

In the first part of this investigation, we document some of the basic facts about the U.S. and Great Britain. For both wars and both countries, we find that output rises and private investment and consumption are crowded out. We also find evidence of significant increases in government investment in fixed capital in both countries. During World War I, the British government financed expansions to critical manufacturing industries such as steel. In the United States, the government invested significant resources in the construction of a merchant marine. Government investment played an even larger role during World War II. In the U.S., if government-owned privately operated (GOPO) capital is added to the private capital stock, the total stock of capital increases during the war. ${ }^{1}$

Properly accounting for GOPO capital has a large effect on total factor productivity

1 Gordon [1969] has estimated that the inclusion of GOPO capital results in a 30 percent increase in manufacturing capital stock between 1940 and 1945 . 
growth during the war. If GOPO capital is ignored, total factor productivity increases at annual rates of 4 percent per year between 1941 and 1944. Once GOPO capital is included in the capital stock, total factor productivity growth falls to 2.7 percent per year. After accounting for changes in utilization we find that total factor productivity grows at 2 percent per year during the war.

In addition to the components of output, we report the responses of labor input and labor productivity for the two countries. In the U.S., labor input increases during both wars. In Great Britain, on the other hand, the evidence suggests that labor input fell. In both countries, we find labor productivity increasing during the wars. The British experience of declining labor input and private investment at a time when output is increasing poses difficulties for both perfectly and imperfectly competitive models. In both frameworks, an increase in government purchases today requires an increase in labor input if output is to increase today. In terms of their prediction for labor productivity during periods of high military expenditures, both theories fail.

These features of the data may be reconciled with theory if the effects of conscription and government investment are explicitly modeled. Conscription shifts the labor supply schedule left thereby increasing labor productivity. Government investment shifts the labor demand schedule right in times of high government spending. With a shift in the labor demand schedule, it is possible to explain the fact that productivity rises in the U.S. during the wars as labor input increases. With conscription and government investment rising together it is also possible to explain the British observation of increasing output in times when labor input is declining.

In the second part of our investigation, we ask the following question: Can a plausibly parameterized specification of preferences and technology deliver the U.S. and British observations? We consider a specification where government capital is an argument of the production technology. The production technology is assumed to be constant returns to scale in private capital, government capital and labor input. Based on our finding that total factor productivity growth was about average during the war we abstract entirely from fluctuations in the state of technology. Instead we focus on the effects of government activity. A Markov process is fit to data on government investment, military expenditures, and military employment. This process is used to simulate wars. We compute optimal decision functions for agents in the model and study their response to shocks of the magnitude of World War II. 
We find that our simple framework does surprisingly well. The model captures a significant fraction of the movement of hours of work, productivity, and the components of GNP. We also find a positive correlation between productivity and government expenditures even when public and private capital are perfect substitutes in production. The rise in productivity comes one period after the increase in expenditures since the capital stock takes one period to adjust. Finally, we show that observations in Great Britain can be explained by including conscription in the model.

The remainder of the paper is organized as follows. Section 2 of the paper documents the U.S. and British wartime experiences. We focus on GNP and its components, the labor market, prices, and financial markets. In Section 3, we describe a simple model that takes into account government-owned privately operated capital. We relate the predictions of the model to the U.S. and British data. We conclude in Section 4.

\section{The Data}

In this section, we describe the effects of World Wars I and II on economic activity in Great Britain and the United States. We discuss the response of GNP and its components, the labor market, prices, and financial markets in the two countries. At the end of each section, we summarize the main findings.

\subsection{Great Britain's economy during World War I}

Great Britain on the eve of World War I had just passed through a period of prosperity. Unemployment, which was about 2 percent, was low by historical standards. With the Balkan war having been settled in the previous year, financial markets were calm and showed no evidence that war was anticipated. For instance, the assassination of Archduke Ferdinand in June of 1914 was interpreted in early July as having had no effect on financial markets (Noyes [1926], page 54). Less than three weeks later international markets were in a state of total collapse. On July 28, Austria declared war on Serbia. Three days later Germany sent its ultimatum to France and Russia. On the same day the London Stock Exchange closed for the first time ever in its history. The U.S. stock market suspended operations the same day.

The scale of the British war effort produced unprecedented demands on industry and the workforce which led to rapid price increases. Between 1914 and 1918 commodity prices rose by over 100 percent. Early examples of profiteering led to the use of price controls which by the end of the war covered "nearly everything that men could eat or drink without being poisoned" (Hancock and Gowing [1949], p. 21). Price controls produced shortages 
which led the British to organize an administrative framework for systematically rationing food items. Although rationing was not imposed until the later stages of the war, lessons were learned that significantly facilitated the use of rationing in World War II.

During World War I the British government made its first effort to systematically control production. Shortages of strategic materials led the government to restrict their export and requisition domestic stocks. The government imposed price controls on many intermediate goods and often directly controlled the allocation of these goods. The government also helped finance expansions to war related industries.

\section{British GDP and its components in World War I}

In the upper panel of Figure 1 we plot the expenditure shares of the components of British GDP. The data which runs from 1910 to 1965 is taken from Mitchell [1988]. From these diagrams we see that the share of government purchases rose from less than 10 percent of GDP to a maximum of about 36 percent of GDP during World War I. This rapid transient rise in the size and scope of government activities is rivaled only by the events of World War II. The increase in government demand was accompanied by both an increase in output and declines in private consumption and investment. Real GDP rose by 17 percent between 1913 to 1917 reaching levels that it did not exceed again for twenty years. The share of investment in output declined by a half over the same period and consumption's share in GDP fell by 20 percent. There were also large changes in the composition of consumption during the war. For instance, consumption of food items fell by only 3 percent between 1916 and 1917, while consumption of household durables declined by 20 percent (Mitchell [1988]). Finally, the war had significant effects on net exports. Between 1913 and 1917 net exports fell sharply as Britain increased imports of foodstuffs and other materials required for the war.

\section{Insert Figure 1 about here.}

The demands of the war produced major changes in the composition of government purchases. Large fractions of the government's expenditure were used to purchase weaponry and to compensate and sustain military personnel. Evidence from the History of the Ministry of Munitions indicates that the government also played an important role in expanding productive capacity during the war. The British steel industry illustrates this point. At the outset of the war the British government encouraged the steel industry to privately finance expansions in capacity. These appeals were successful early in 1915 but soon thereafter met with resistance. Producers pointed to uncertainties in the market 
for steel after the war and argued that the excess profits tax would make it impossible for them to achieve a reasonable return on their investment. After a series of negotiations in March of 1916 the government settled on a formula for assistance that called for the producers to pay a minimum of 25 percent of the total cost of expansions to capacity (History of the Munitions Ministry, vol. 7, p. 58). By the end of the war the government had provided financial assistance to 365 projects to expand steel production. The government's assistance of 23.4 million pounds amounted to 52 percent of the total cost of these projects.

The government also played a significant role in financing the development of a domestic optical glass industry, the domestic production of tungsten, and the expansion of copper production.

\section{The British Labor Market in World War I}

The British war effort required a large increase in work effort at the same time that significant fractions of the workforce were being drawn into the military. Panel A of Table 1 summarizes the effects of these competing demands on the labor market. Notice first that the size of the military increased from 400 thousand in 1913 to over 4.4 million in 1918. This buildup in the size of the military is even more remarkable given that the unemployment rate of 2.1 percent was at a historically low level (Mitchell [1980]). During the war unemployment dropped to a low of 0.4 percent in 1916. The figures in Table 1 show steady declines in civilian employment throughout the duration of the war. By 1918 civilian employment had fallen by over 2 million from its peacetime level of 19 million in 1913. This decline in civilian employment wis arcompanied by large changes in the composition of employment. Data in Mitchell [1948] on union membership show total membership rising by more than 50 percent $b+\ldots \cdots+n 1913$ and 1918. Female membership rose by 179 percent. After the war both civili.n 'mployment and the unemployment rate rose as the size of the military was reduced. Fimale participation in the work force as measured by union memberships remained high through 1920 and then declined leveling off at about twice its prewar level.

\section{Insert Table 1 about here.}

Data on hours worked is sketchy. Maddison [1989] reports that average hours per year in Britain in 1913 were 2624 while Mitchell [1988] reports average annual hours were 2753 in the same year. These figures suggest that average hours per week were somewhere between 53 and 56 on the eve of World War I. Bowley [1921] reports that weekly hours 
were reduced in 1919 by an average of 6.5 hours. Using prewar hours this reduction implies postwar work weeks between 46 and 48 hours. While direct measurements of hours worked are not available during the war, days lost to labor disputes fell sharply and anecdotal evidence points to an increased use of part-time employees, significant flows of labor from the agricultural sector to manufacturing and extensive use of overtime. However, it appears unlikely that these factors could have produced a rise in total civilian hours during the war. If we assume that weekly hours were 53 and multiply this estimate by the 1913 civilian employment figure in Table 1, then total weekly civilian hours in 1913 are about 1 billion. In order for weekly civilian hours to maintain this level in 1918, per capita weekly hours would have had to increase by 9 hours. ${ }^{2}$ An increase of this magnitude seems implausible. By way of comparison, in World War II weekly hours increased by only about 3 hours per week. Moreover, in World War II, workers started from a lower base of 46.5 hours per week.

The difficulties in measuring labor input during World War I clearly affect our ability to measure labor's productivity. Feinstein [1972] reports output per worker using total employment (civilian and military) and his compromise factor cost measure of real GDP. This measure of labor productivity which is reported in Table 1, rises by a total of 7 percent between 1913 and 1918.

Real wages during World War I decline between 1915 and 1917 and then recover in 1918, with net gains in real wages in 1919 and 1920. Bowley [1921] (pp. 105-106) reports indices for a number of occupations ranging from bricklayers to engineering artisans. Using his cost of living index, increases in wage rates in 1918 offset the declines in the earlier years. Table 1 reports an index of real wages from Feinstein [1972]. In constructing this index nominal wage rates were deflated by the Labour Gazette cost of living index. Bowley [1921]; (pp. 63-75) documents several factors that lead this index to overstate increases in the cost of living during World War I. But, the basic pattern of declines in 1915-1917 with subsequent rises from 1918-1920 is similar for both measures of real wages.

\section{Prices in Britain During World War I}

Prices increased at unprecedented rates during World War I. The Labor Gazette index rose by 110 percent between 1914 and 1918. The Bowley index rose by 85 percent over the same interval. Mitchell [1919] reports even faster growth in commodity prices. Between 1914 and 1918 Mitchell's index of 150 commodity prices increased by 140 percent.

\footnotetext{
2 This calculation holds fixed the number of weeks worked per year.
} 
Incidents of hoarding and profiteering led the government to take direct control of key industries and and impose price controls on many intermediate and final goods. These controls often took the form of cost plus formulas which meant that production costs had to be calculated and reasonable markup margins determined. Excess profits taxes were also adopted which limited the gains from profiteering, but, also dampened investment incentives.

Food supplies in Great Britain were not seriously affected until 1917. Price controls were first implemented on food items in the summer of 1917. However, it was not until food shortages arose in late 1917 and early 1918 that rationing was extended to items other than sugar. Initially, consumers were required to register with a particular retailer who then became the consumer's sole supplier of rationed items. Ration coupons were added to this registration requirement between February and July. These programs were largely successful in eliminating the queuing which had occurred in late 1917 for items like butter and meat.

Shortages of skilled labor produced bidding contests among employers at the start of the war. To control the upward pressure on wages the Munitions Control Act of 1915 included a Code of Labour Regulation that prohibited workers from accepting new employment without written permission from their current employer. However, the Code of Labour Regulation provoked widespread resentment among workers and was abandoned in August of 1917.

\section{Financial Markets in Britain During World War I}

The rapid inflation during World War I had a significant effect on real interest rates. Homer and Sylla [1991] report that nominal yields on consols rose steadily during the war from 3.46 percent in 1914 to 4.62 percent in 1919. Similarly, government issues rose from 3.96 percent in 1914 to about 6 percent in 1920. However, these increases in nominal yields were small relative to the price increases documented above. After accounting for the effects of inflation ex post returns are negative for the duration of the war.

\subsection{The United States Economy During World War I}

The outbreak of war in Europe caused financial panic in the United States. The U.S. stock market suspended operations on July 311914 to avoid facing an onslaught of panic sell orders from Europe. Expectations that trade flows would be disrupted produced steep declines in commodity prices for cotton and wheat. The prices of many other other traded goods like copper, steel, meat and oil fell as well. In contrast to the Europeans who placed 
embargoes on exports of gold at the outbreak of war, the U.S. continued to honor its gold obligations. The initial panic in the U.S. subsided rapidly as it became clear that the war would increase demand for many U.S. goods. After the U.S. entered the war in April of 1917 further disruptions occurred as the country mobilized for war. The Armistice was signed on November 11, 1918 nineteen months after the United States' entry into the conflict.

\section{U.S. GNP and its Components During World War I}

The U.S. experience in World War I was similar to the British experience in many respects. The lower plot in Figure 2 displays the shares of the expenditure components of GNP. As in Britain, World War I produced major changes in the composition of output. While the magnitude of the U.S. war effort was much smaller than in Britain, the pattern of responses of consumption and investment were quite similar. Increased government spending acted to crowd out private consumption and investment. Net exports, which were negative in 1913, rose rapidly after the outbreak of hostilities and peaked at 6 percent of GNP in 1916.

\section{Insert Figure 2 about here.}

In the course of the war, the U.S. government devoted a small, but, significant fraction of its expenditures to activities that expanded the country's productive capacity. The disruption of trade flows in Europe and the neutrality of the United States created a demand for U.S. goods that quickly absorbed the resources of the entire U.S. merchant shipping fleet. To help meet the shortage of merchant shipping, the United States Shipping Board was established. The goal of this government enterprise was to provide a supply of merchant vessels that could support naval form in the case of war and facilitate foreign commerce with other neutral countries. By $+h_{1} \cdots \cdots+$ of the war the government had signed contracts to build 3,116 freighters with a dear $/ \cdots \cdot 1 n$ hit tonnage of $16,914,047$ tons. This was equal to a third of world merchant tonnage in 19133 (Crowell [1920]). As of December 31, $1918 \$ 2,769,337,500$ had been authorized for ship construction under this program. This amount was twice the navy's ship building budget and about 4 percent of GNP in 1918 . The U.S. government made further investments in munitions and industrial plants of about $\$ 600$ million and sold $\$ 2.2$ billion of trucks and buses (original cost) after the war (Cook [1948]).

\section{The U.S. Labor Market During World War I}

Panel A of Table 2 contains information on aggregate labor market statistics for 
the U.S. during World War I. Consider the patterns in civilian employment. Kendrick's measure of persons engaged increases from 1914 through 1917, and then declines in 1918, the year where conscription reached its peak. This pattern is different from Britain, where civilian employment dropped steadily throughout the entire war. One reason for this difference is the smaller migration of manpower into the armed services. At its peak the U.S. armed forces were only 65 percent the size of the British. Figure 2 also contains Kendrick's measure of manhours divided by the population over 16 . This measure shows an increase in labor input during World War I. Kendrick's measure of labor productivity is listed in column five. Labor productivity declines in 1917 and then recovers in 1918. Once trend growth is taken into account, these data show no strong pattern in labor productivity during World War I. Finally, note that real wages are basically constant until 1917, and then increase in 1918-1920.

\section{Insert Table 2 about here.}

\section{Prices in the U.S. During World War I}

The evolution of prices in the United States during the war is similar to patterns already documented in Britain. Between 1913 and 1918 the CPI increased by 57 percent and by 1920 , prices had risen by 133 percent. These increases are on a comparable scale with the British experience, although U.S. prices started rising somewhat later than in Britain. Commodity prices in the U.S. also closely mimic the evolution of British prices for comparable items. Commodity prices rose by 110 percent between 1913 and 1918. In both countries the sharpest increases in commodity prices occurred in 1916 and 1917 and then stabilized in 1918 as government price controls were extended.

Price controls were put into effect shortly after the U.S. entered the war in response to rapidly escalating prices. For instance, steel plates doubled in price during the first 5 months of war and food prices rose by 28 percent over the same period(see Mitchell 1919). Price controls on food were effected by licensing requirements. Licenses were required for merchants who imported, manufactured, stored or distributed specified items. Farmers, gardeners and small businesses were exempted. Penalties were set for hoarding goods, destroying goods with the intent to drive up prices or making excessive profits. Violators were subject to fines ranging from $\$ 5-10000$ dollars, the revocation of their licenses and jail sentences for serious violations (Mitchell [1919]). In practice prices were not directly fixed: rather markups were limited by "reasonable margin-of-profit" rules. Reasonable profit margins were initially based on prewar profit margins but, as the war advanced 
this was replaced by a two tier system with distinct margins for high-cost and low-cost dealers. While price controls led to shortages of some items (e.g. sugar), a formal system of rationing was not used for consumer items in World War I. Instead the government relied on appeals to dealers to limit sales to each customer of items in short supply (Rockoff [1984]).

Wage controls were not applied in the U.S. during World War I. Instead the government took an active role in matching workers with employers and mediating labor disputes. In a few rare instances, the government seized key industries where labor problems were particularly acute. The most notable example was Smith and Wesson. Labor disputes also played a role in the government's decision to take over the railroads.

Taken together these measures were largely successful in bringing inflation under control by the beginning of 1918 (Rockoff [1984], p. 69).

\section{U.S. Financial Markets During World War I}

One result of war in Europe was that New York assumed London's position as the leading center of international finance. European powers floated large loans in the U.S. during the war, and by the war's end nearly half of the world's gold reserves were located in the U.S. In the period from 1915 to 1917 (nominal) yields on bonds tended to decline (Homer and Sylla [1991]). However, the U.S. entry into war produced a decline in the bond market. Yields on prime corporate debt rose from 3.98 - 4.98 percent between January and October of 1917. Commercial paper rates rose from 3.84 percent in 1916 to 5.07 in 1917. Yields on Liberty.government bonds, which were tax exempt, rose quickly after their issue at 3.5 percent to 3.61 percent. These yields appear to be low given the rapid escalation of prices during this period. Ex post real rates on commercial paper were negative between 1915-1917 and in 1919.

\subsection{A Comparison of U.S. and British Experiences in World War I}

Our analysis, of the British and U.S. economies shows three common features during World War I. First, the response of the major components of output was the same in both countries. The increased government demand for goods raised output and crowded out private consumption and investment in both countries. Second, significant fractions of government purchases were used to expand productive capacity during the war. For example, in Great Britain, the government helped finance expansions to the steel industry. In the United States, the government took a lead role in expanding the merchant marine. Third, labor productivity increased in both countries. In Great Britain, output per worker 
rose, and the available evidence points to increases in output per manhour as well. In the United States, labor productivity fell in 1917 and then recovered in 1918.

The most striking difference between the United States and Great Britain was in the response of employment. In Great Britain, civilian employment fell steadily throughout the war. In the United States, civilian employment was steady in 1917 and 1918. This difference is most likely due to the fact that Great Britain lost a much larger fraction of its labor force to the armed forces.

\subsection{Great Britain's economy during World War II}

The British government's actions in World War II were heavily influenced by its experience in World War I. For instance, rationing was widely viewed as having been successful in ending the queues that formed in the winter of 1917-1918. Thus, when war broke out again rationing of food items was quickly reinstated. Wage controls, on the other hand, were considered to have been a failure, and thus were not used in World War II. The experience of the First World War also influenced firms actions. The severe recession that followed World War I penalized many of the firms that had responded to the government's pleas by expanding capacity with their internal funds. As a result, the British government was compelled to finance a substantially larger fraction of the expansions to productive capacity in World War II.

British GDP and its components During World War II

The scale of the "Great War" was dwarfed within twenty-five years by World War II. Figure 1 shows that at its peak government purchases accounted for nearly half of Britain's GDP. This massive increase in government demand reduced private investment to levels not experienced since World War I. Consumption fell to levels not seen in ten years. As in World War I, the decline in durable household consumption items was large. Real expenditures on household durables goods fell by 74 percent between 1939 and 1944 while real food expenditures fell by 13 percent (Hancock [1951], p. 203). Net imports also surpassed levels in the first war reaching a maximum of 13 percent of GDP in 1940, the year before the Lend-Lease Program began.

One of the more important distinctions between World War II and World War I is the increased importance of government assistance in financing investment. In the Second World War, firms were again unwilling to fund expansion of their facilities. With excess profits taxes of 100 percent and government regulation of prices private operators argued that the return from investing in plant expansion was likely to be small or even negative. 
The steep recession that followed the First World War provided additional fuel for their arguments.

The government's investment in fixed capital fell into three categories: direct assistance to firms; investment in government agency projects that were government owned but privately operated; and investment in government-owned government- operated facilities. In cases where the government's needs could be met by expanding current facilities, it offered assistance in financing the project. This assistance had two forms: contributory schemes and 100 percent government financing. For contributory schemes, the government would offer to pay up to 60 percent of the cost of the project. Title of the project was given to the firm and the firm paid rent on the government's share of the investment ranging from 4 to 6 percent per annum for the course of the war. Under the second form of assistance the government contributed 100 percent of the costs and retained title to the project. In addition, the government limited the firm's return on the government owned capital to an average of 2 percent although rates of return varied widely (Ashworth [1953], ch. 12). Government investment in government agencies typically involved the construction of new plants. Private operators were then contracted to manage operation of these facilities. The smallest of the three categories, government-owned government-operated facilities, were typically armaments factories, many of which had been built during World War I.

Total government investment in fixed capital amounted to 1.2 billion pounds between 1937 and 1945. Of this total, 50 percent fell in the category of government assistance to private firms, 25 percent went to agencies, and the remaining 25 percent was for government operations. Government expenditures on fixed capital were over 3 percent of GDP in 1940 and 1941 and then declined to about 1 percent of GDP after the U.S entered the war (Ashworth [1953], pp. 252-253).

\section{The British Labor Market During World War II}

The British labor market in World War II bears many resemblances to the labor market in World War I. Panel B of Table 1 reports basic labor market statistics for the period 1938 through 1945. As in World War I, civilian employment fell steadily throughout the entire war period. Unemployment rates fell to the same levels observed in World War I. The availability of data on hours during World War II is only slightly better than for World War I. Hancock [1951] reports that average weekly hours increased from 46.5 in the last quarter of 1938 to a maximum of 50 in 1943. Given the measured decline in employment 
between 1939 and 1945 it appears unlikely that manhours increased significantly during the war.

Finally, note that real wages and output per worker moved in opposite directions during the war. Feinstein's [1972] measure of output per worker shows an initial dip in 1939 , followed by increases through 1943. Real wages, on the other hand, declined from 1939 until 1942 and do not exceed their prewar level until 1945.

\section{Prices in Great Britain During World War II}

Price increases during World War II were more moderate than in World War I. The Labor Gazette's cost-of-living index increased by 43 percent between 1939 and 1945, which was less than half the increase observed in World War I. The smaller growth in prices during World War II reflects the success of government price control and rationing programs. Responsibility for price controls on consumer goods was divided between two agencies: The Ministry of Food and the Board of Trade. The Ministry of Food was given exclusive control over food imports and used this authority, for instance, to purchase virtually the entire sugar crop produced in the British Empire in 1939. The Ministry of Food also was responsible for setting maximum prices for food products at the wholesale and retail levels and for rationing staples such as sugar and meat. Rationing was imposed on butter, bacon, sugar and meat shortly after war was declared. As the war progressed, piecemeal rationing of particular items was replaced by a point system. The Ministry of Food also subsized items ranging from milk to meat and flour. Controls for nonfood consumer goods were the responsibility of the Board of Trade. Price increases were controlled by limiting markups to prewar levels plus an additional percentage to cover their increased costs. Wages were one of the few items not controlled. On the basis of its experience with labor market controls in World War I the government decided to let wage differentials draw laborers into sectors where their services were needed most.

\section{Financial Markets in Great Britain During World War II}

The outbreak of World War II was widely anticipated and thus did not produce the panic selling that occurred in World War I. Stock market prices in Great Britain started falling in 1937, reaching a low point in June of 1940 during the Dunkirk evacuation. After the evacuation, prices started a recovery that lasted until the end of the war. New security issues fell dramatically during the war due to controls imposed by the government. The yield on consols rose from 2.65 percent in 1935 to a high of 4.1 percent in 1939 and then fell steadily through the second war falling to a low of 2.51 percent in 1946 . The average 
yield of bonds of maturity thirty years or longer fell from a high of 3.62 percent in 1939 to a low of 2.53 percent in 1946. The Bank rate was fixed at 2 percent during the war and government bonds were issued at 3 percent (Homer and Sylla [1991]).

\subsection{The United States Economy During World War II}

The United States declared war on Japan and Germany on December 7 1941. Preparations for war, however, had begun eighteen months earlier. During the Second World War the government adopted many of the same strategies used by Britain. Price controls were widespread and government mandates curtailed production of many consumer durables. Rationing of food items was introduced in 1943. The marshaling of resources achieved by the United States during the Second World War is unprecedented. It took ten years for real GNP to exceed its wartime peak.

\section{U.S. GNP and its components During World War II}

As in World War I, the outbreak of hostilities in Europe brought an initial period of prosperity to the United States. Real GNP grew at about 7 percent per year in 1939 and 1940 before it started accelerating in 1941. Between 1941 and 1944 real GNP increased by 52 percent. The responses of aggregate expenditures shown on the lower plot of Figure 1 are familiar: a massive increase in government purchases that is associated with large increases in GNP, and significant crowding out of private investment.

An interesting property of this data is the positive growth in consumption between 1943 and 1945. Real consumption expenditures fell between 1941 and 1942 and then increased during the remainder of the war. There were also large changes in the composition of consumption during the war. In 1942 production of automobiles for nonmilitary purposes was halted and production of many other consumption durables was curtailed. These actions produced a large decline in the share of durables in total consumption.

Government purchases also exhibited significant compositional shifts during World War II. Before the war, government purchases of goods and services were dominated by services, which accounted for 65 percent of federal purchases in 1938. In 1938 durable goods constituted 5 percent of federal purchases and structures added another 10 percent. The share of nondurables was 9 percent. By 1942, the composition of purchases had shifted sharply towards durable and structures. Durable goods had risen by a factor of eight and accounted for 24 percent of total purchases, while structures had risen by a factor of 12 and made up 17 percent of total purchases. Spending on durables and structures started rising in 1940 as the country began preparing for the possibility of war. Nondurables 
and services rose later as the costs of raising and.maintaining the armed forces mounted. Approximately 80 percent of the increase in the services component between 1938 and 1943 was due to increases in total wages and salaries paid to military employees. ${ }^{3}$

One problem with the National Income and Products Account data on government purchases is that it fails to show the uses of the investment components. During World War II, the investment component was large. The Federal Government financed large increases in industrial construction and producer's equipment that increased the productive capacity of the automotive, aircraft, and aluminum industries. In addition, large fractions of the government's investment in fixed capital was used by private industry after the war. Gordon [1969] estimates that 12 billion dollars (valued at historical cost) worth of structures and equipment financed by the government during the war was used by postwar private operators. (See also Jaszi [1970] and Gordon [1970].) For purposes of comparison total private investment over the same period was 11.4 billion dollars.

\section{Insert Figure 2 about here.}

Figure 2 shows the private gross manufacturing stock of equipment and structures, and the gross stock of government-owned privately operated (GOPO) equipment and structures from 1939-1954 expressed in 1958 dollars. The data is from Wasson, Musgrave and Harkins [1970]. Note that the inclusion of GOPO capital provides an entirely different picture of the war. If GOPO capital is left out, the capital stock falls during the war. If government capital is included then the war is a period in which significant additions were made to the country's productive capacity.

Some general information on the types of investments that the government undertook are recorded in the October 1944 issue of Surre " of Current Business. The Survey estimated that 90 percent of magnesium capacitv. $1 . ;$ prent of aluminum capacity, 20 percent of blast furnace capacity and 10 percent of $-1, \cdots \cdot-m$ making furnaces was government owned at that point in time. Cook [1948] and Gortun 19699] provide more details on the nature of projects in which the government invested. some of the larger investments include $\$ 1.3$ billion to expand steel capacity, $\$ 3.8$ billion in aircraft plants, $\$ 704$ million in aluminum plants, and $\$ 700$ million in synthetic rubber plants. After the war, significant amounts of GOPO capital were sold to the private operators at an average of 27 percent of the historical cost. However, as Figure 2 illustrates GOPO capital continued to constitute an

3 These calculations are based on figures reported in The National Income and Product Accounts of the United States, 1929-1982 [1986]. 
important fraction of the manufacturing capital stock through the postwar. ${ }^{4}$

Correctly accounting for the investment component of government purchases has a large effect on the properties of Solow's residual. Table 3 summarizes the average growth rate of total factor productivity between 1937 and 1947. Results are reported for three subsamples, 1938-1941, 1941-1944 and 1944-1947. The percentages reported in the table are total growth for the subperiod. The upper panel contains results for the entire U.S. economy. In the upper panel output is measured using real GNP in 1982 dollars net of government compensation of employees. The measures of labor input and capital are varied as we move across the columns. In column one labor input is measured using Kendrick's [1961] index of labor input in the private economy and the capital stock using data on the stock of capital of equipment and structures for all industries measured in 1982 constant dollars as reported in Fixed Reproducible Tangible Wealth in the United States [1987]. Column two uses the same measure of labor input and augments the capital stock to include GOPO capital as reported in Wasson, Musgrave and Harkins [1970].

The third column uses private capital plus GOPO capital to measure the total capital stock and makes adjustments for utilization of capital. In Appendix B we describe a model that allows for variation in the workweek of capital. This specification yields the following aggregate production technology:

$$
y_{t}=k_{t}^{\theta} n_{t}^{(1-\theta)} h_{t} z_{t}
$$

where $n_{t}$ represents the fraction of the population employed, $h_{t}$ is hours per worker, $k_{t}$ is the capital stock (per capita), $y_{t}$ is per capita output and $z_{t}$ is the technology shock. Results in column three use Kendrick's [1961] measure of private sector employment divided by civilian population over sixteen from U.S. Historical Statistics to measure $n_{t}$, and $h_{t}$ is constructed by dividing out previous measure of labor input by private sector employment. The variables $y_{t}$ and $k_{t}$ are also expressed in per capita terms. In this representation hours per worker indexes the intensity of utilization of the two inputs: capital and labor. Finally, note that all columns assume a capital share of $\theta=0.25 .^{5}$

\section{Insert table 3 about here.}

Looking first at the period from 1941 through 1944 observe that the productivity calculation in column one suggests that a large positive technology shock occurred during

4 Many of these facts have been documented previously by Gordon [1969].

5 The capital share parameter value here is lower than the values used by Prescott [1986] or Christiano [1988] who add an imputed service flow of consumer durables to output. 
the war. Total factor productivity growth in the peacetime averages about 2 percent per year. Subtracting this from the reported growth of 4.3 percent leaves 7 percent unexplained between 1941 and 1944. In column two GOPO capital is added to the capital stock. This adjustment reduces total factor productivity growth to 2.5 percent per year thereby reducing the unexplained growth to 2 percent over this three year period. Once the effects of changes in utilization are accounted for, productivity growth between 1941 and 1944 is about average at 1.8 percent per annum.

The nine years from 1938 to 1947 covers the period between the last prewar trough to the first postwar trough. In this period if GOPO capital is ignored total factor productivity exhibits strong growth before the war and slows considerably after the war. Overall, total factor productivity increases by 20 percent over this period or about 2 percent above trend. Accounting for GOPO capital attenuates the swings in total factor productivity and reduces the growth in total factor productivity over the period to 17 percent which is slightly below trend. Adjustments for changes in capacity utilization reduce the growth during this period further to 16 percent.

\section{The U.S. Labor Market During World War II}

A second important factor explaining the remarkable growth in GNP during World War II was growth in labor input. Panel B of Table 2 shows some of the main features of the labor market during the second war. Employment started rising as Europe began to prepare for war and rose further after war broke out in 1939. One of the more remarkable features of World-War II was the strong growth in employment after the U.S. entered the war. Civilian employment continued to increase steadily through 1943 even as armed forces were increased from 4 to 9 million. The changing composition of government demand is also reflected in more disaggregated labor market statistics. For instance, employment in durable goods manufacturing increased by over 150 percent between 1938 and 1944 while employment in nondurable manufacturing increased by only 30 percent.

Per capita manhours also grow strongly increasing by 9 percent between 1941 and 1943. While some this growth came from the increases in employment documented above weekly hours increased significantly as well. The National Industrial Council Board's index of weekly hours increased from 41.7 hours per week in July of 1941 to 47.9 hours per week in July of 1944. In some vital industries like machine tools the average work week increased by as much as 10 hours during the war. ${ }^{6}$

6 See various issues of the Survey of Current Business [1941-4]. 
Labor productivity growth is not very strong during World War II. Kendrick's measure is essentially flat in the first two years of the war and then increases. If we assume average growth of about 2 percent per year, Kendrick's measure is below trend in 1942 and 1943 and above trend in 1944 and 1945. It is interesting that the strongest growth in average productivity coincides with the periods when conscription rates reach their maximum.

Finally, as Rotemburg and Woodford [1992] have emphasized, wages in manufacturing increased rapidly during the Second World War. Underlying this growth was a sharp increase in wages in durable goods industries. In other sectors of the economy wage rates fell. Bry [1961] (p. 316), for instance, reports steady declines in real wage rates for skilled construction workers during World War II.

\section{Prices in the U.S. During World War II}

General price controls were introduced in March of 1942 in the form of a price freeze. Over time, this freeze gave way to cost-plus rules similar to those used in Great Britain. Merchants were allowed to pass on cost increases as long as their markup was not altered. As in Britain, price controls slowed but did not halt inflation. Between 1941 and 1945 the CPI rose by about 22 percent. Food rationing was introduced in 1943. Rockoff [1984] reports that average values of nutrition under rationing exceeded prewar nutrition levels. In addition, large black markets existed for more expensive food items like meat. As noted above, many consumer durables were rationed by government edicts curtailing or halting production of items like typewriters and stoves. Wages were controlled by the National Labor Board which prohibited wage growth rates in excess of the CPI growth rate. However, these controls were frequently c ircumvented by offering inducements like vacation, medical insurance and promotions.

\section{The U.S. Financial Market in World War II}

Bond yields were low before the start of $h_{1}$ war. In 1938, bond yields averaged 2.94 percent. Homer and Sylla [1991] report inst.11... in 1938 where nominal treasury bond yields sold at negative yields due to the tax status of these issues. Between 1938 and 1940 the yield on corporate bonds, municipal bonds and treasury bonds declined even further and then stabilized after the U.S. entered the war. During the war the Treasury and Federal Reserve coordinated their polices in order to maintain a constant price schedule for government debt issues. The U.S. Stock market during World War II experienced a gradual decline from 1937 to 1942 and then started to climb again midway through 1942.

\subsection{Summarizing the Effects of the World Wars on Economic Activity}


The economic responses that we have documented in the previous subsections are the largest economic events of the twentieth century. Consider the correlations reported in Table 4 for Great Britain and the United States. The two panels report correlations of various aggregate variables with output and military expenditures. The sample period extends from 1910 to 1965 for Great Britain and from 1910 to 1968 for the U.S. Results are reported for variables expressed in terms of deviation from trend. Definitions of the series can be found in the data appendix. Many of the patterns that we have described above are reflected in these correlations. Military purchases (Mil) is positively correlated with output (GNP) and negatively correlated with consumption (C), investment (I) and net-exports (Netx). either transformation of the data. As expected, government expenditures (G-EXP) and revenue (G-REV) are positively correlated with GNP and military expenditures. As we noted earlier, civilian employment (Emp-Civ) and wages (Wage) are negatively correlated with military expenditures and output per worker (GDP/Emp) is positively correlated with expenditures. Finally, ex-post real returns on interest rates (RR-long) are negatively related to military outlays. The pattern of output correlations also reflect the dominant effects of the two wars. Consumption is only weakly procyclical, and investment, real wages and interest rates are all countercyclical. ${ }^{7}$

\section{Insert Table 4 about here.}

In Table 4, we report correlations of available U.S. time series with GNP and military expenditures. The definitions of series listed in column 1 are given in the data appendix. Notice that the correlations with military outlays are consistent with the patterns documented above for the two wars. Consumption (C) and investment (I) are negatively correlated with military outlays (Mil). Revenues (G-REV) and expenditures (G-EXP) are positively correlated with military outlays. Hours $(\mathrm{H})$, labor input $(\mathrm{N})$, real wages (Wage) and both measures of productivity (GNP/H,GNP/N) are positively correlated with military outlays. Interest rates, on the other hand, (RR-long, RR-short), are negatively correlated with military outlays. Finally, observe that the correlations of GNP and consumption and investment are positive while the correlations of military expenditures and consumption and investment are negative. This result is in part due to the fact that are sample includes non-war periods when other shocks (e.g., technology shocks) are important.

What general lessons can we draw from these experiences about the effects of large

\footnotetext{
7 Correia, Neves and Rebelo [1992] have documented this property of British data previously.
} 
increases in government purchases? First, the response output and its components is similar in both countries. The large increases in government expenditures increased output and crowded out consumption and investment in both countries during both wars. Second, both governments took an active role in directing investment into activities that were vital to the war effort and financing these expenditures directly when firms could not be induced to do so. The evidence suggests that the two governments were more active in financing investment in World War II than in World War I. In the United States, the picture of a contracting capital stock during the second World War that emerges from the National Income and Product Accounts ignores the significant expansions in capacity financed by the U.S. government. Third, labor productivity increased in both countries during the two World Wars.

Other labor market patterns vary across time and the two countries. In Great Britain there appears to be a fall in labor input in both wars whereas labor input increases in the United States. This difference is most likely due to the effects of conscription. British armed forces at their peak accounted for about 20 percent of the total labor force in both world wars. The United States armed forces did not reach this rate until 1944 which is the first year that labor input declines. In Great Britain, civilian employment plus the armed forces constituted 50 percent of total population in 1943. In the United States, civilian employment plus armed forces at their peak were only 44 percent of the total population.

Some of these facts are consistent with the predictions of neoclassical theory. Hall [1980], Barro [1981] and Aiyagari, Christiano and Eichenbaum [1992] have found that the neoclassical framework predicts temporary increases in government purchases should increase output, crowd out consumption and private investment and raise employment. However, this framework also predicts that labor productivity and wages should fall. Negative wealth effects in conjunction with intertemporal substitution effects lead households to work harder today and consume less today. In the labor market these effects shift labor supply out along an (essentially) stable labor demand schedule.

Conscription may resolve the productivity puzzle and the patterns of employment observed in Great Britain. In isolation, conscription reduces households' time endowment. This in turn, shifts labor supply left in the civilian sector which results in a rise in labor productivity and lower civilian employment.

Government investment may also explain the measured increases in productivity in the two countries. Increases in government investment can shift out the labor demand 
schedule and thereby increase labor productivity. With the labor demand schedule shifting out, the contemporaneous increase on labor input and labor productivity observed in the United States is no longer a puzzle. Moreover, when government investment is modeled in conjunction with conscription, the British experience of increased output and productivity in a period where labor input and private capital input are declining is less puzzling.

In the next section we will examine the effects of conscription and government investment in a neoclassical framework. The central focus of this analysis will be to investigate the role of conscription and government investment in explaining the basic facts we have documented for the Great Britain and the United States.

\section{The Model}

To isolate the effects of government consumption, conscription, and government investment during wartime, we focus on a very simple abstraction. ${ }^{8}$ Let $h_{t}$ be the number of hours spent producing goods in period $t$ and let $a_{t}$ be the number of hours in the army in period $t$. If there is one unit of time to allocate, then leisure in period $t$ is given by

$$
\ell_{t}=1-h_{t}-a_{t}
$$

We assume that the preferences of a typical household depend on their consumption of goods and leisure, e.g.

$$
E\left[\sum_{t=0}^{\infty} \beta^{t} u\left(c_{t}, \ell_{t}\right) \mid x_{0}\right]
$$

where $c_{t}$ is consumption in period $t, \beta$ is a discount factor, $x_{0}$ is the state of the world in date 0 which is taken as given by households, and $E$ is an expectation operator conditioned on the initial state.

There is a technology available to the households that requires inputs of labor and capital. Households can invest and, thus, accumulate private capital. They also receive public capital for private production. The resource constraint for the economy is

$$
c_{t}+i_{t}+i_{g, t}+b_{g, t}=y_{t}=f\left(k_{t}, k_{g, t}, h_{t}\right)
$$

where $i_{t}$ is private investment in period $t, i_{g, t}$ is government investment in $t, b_{g, t}$ is government consumption in $t, k_{t}$ is the private capital stock in $t, k_{g, t}$ is the stock of government

8 We include hours in the army and abstract from distortionary finance, public services, and shocks to technology. Related papers are Aiyagari, Christiano, and Eichenbaum [1992], Barro [1981], Baxter and King [1990], Hall [1980], and Ohanian [1993]. 
capital in $t, y_{t}$ is output for the private sector in $t$, and $f$ is the production function which exhibits constant returns to scale with respect to all three inputs. Note that the production function does not depend on an exogenous technology shock. Both the private and the public capital stock are assumed to depreciate at a rate of $\delta$ per period, e.g.,

$$
\begin{aligned}
k_{t+1} & =(1-\delta) k_{t}+i_{t} \\
k_{g, t+1} & =(1-\delta) k_{g, t}+i_{g t} .
\end{aligned}
$$

In period $t$, all agents know the history of the state. Thus, current consumption, labor, and investment decisions will depend on the history $\left\{\left(k_{s}, k_{g, s}, a_{s}, i_{g, s}, b_{g, s}\right), s=0, \ldots, t\right\}$. Assume that military hours, government investment, and government expenditures are Markov processes (of order $q$ ) which are known to the agents. Then consumption, investment, and labor decisions are functions of current values of the state, e.g., $\left(k_{t}, k_{g, t}, z_{t}, \ldots, z_{t-q}\right)$ in period $t$ where $z_{t}=\left(i_{g, t}, b_{g, t}, a_{t}\right)$.

Let $x_{t}=\left[k_{t}, k_{g, t}, z_{t}, \ldots z_{t-q}\right]$ be the vector of state variables at date $t$. An equilibrium for this economy is a set of decision functions $c\left(x_{t}\right) i\left(x_{t}\right)$, and $h\left(x_{t}\right)$, and a law of motion for the state, $x_{t+1}=\gamma\left(x_{t}\right)$, such that households maximize (2) subject to (1), (3), (4), and processes for government consumption, investment, and military employment.

This model can be used to quantify the effects of government consumption, investment, and conscription on the economy during wartime. This involves choosing a parameterization of preferences and technology, solving for the equilibrium decision functions, and using the decision functions and some process for the exogenous shocks to simulate time series.

The functional forms that we use for utility and production are as follows:

$$
\begin{aligned}
u\left(c_{t}, \ell_{t}\right) & =\frac{\left(c_{t}^{\gamma} \ell_{t}^{1-\gamma}\right)^{1-\omega}-1}{1-\omega} \\
f\left(k_{t}, k_{g t}, h_{t}\right) & =\lambda\left(b k_{t}^{\rho}+(1-b) k_{g t}^{\rho}\right)^{\frac{\theta}{\rho}} h_{t}^{1-\theta}
\end{aligned}
$$

with

$$
\beta=0.96, \gamma=3, \omega=1, \lambda=3 / 2, b=1 / 2, \rho=1, \quad \text { and } \theta=1 / 4 .
$$

For the discount factor, we choose $\beta=0.96$ which corresponds to a 4 percent annual interest rate. A value of 3 for $\gamma$ implies weights of $\frac{1}{4}$ and $\frac{3}{4}$ on consumption and leisure in utility. With $\omega=1$, the utility function has a logarithmic form. To calculate the annual depreciation rate, we projected $i_{t}-\left(k_{t+1}-k_{t}\right)$ onto $k_{t}$ using U.S. data. The resulting 
estimate of $\delta$ is 6.54 percent. This rate of depreciation is also used for Britain. A value of $\frac{1}{4}$ for $\theta$ implies that the capital share of income is 25 percent. The values of $\rho=1$ and $b=\frac{1}{2}$ for technology imply that private and GOPO capital are perfect substitutes in production. The constant $\lambda$ determines the scale of the components of output. A value of $\frac{3}{2}$ was chosen so that the steady state values of these variables lie between 0 and 1 . For the most part, our choices of the utility and technology parameters and the parameters of the Markov chain imply that the first moments of $c_{t} / y_{t}, i_{t} / y_{t}, k_{t} / y_{t}$, and $h_{t}$ in the model are approximately equal to the sample means of the U.S. data during the postwar period. The differences between the first moments of the U.S. and British data are due primarily to differences in government expenditures and conscription. Therefore, we use the parameters of (5) for both countries. In our final remarks we describe how the above choices affect our results.

To compute the equilibrium decision functions, assume that the vector of exogenous variables is a Markov chain. Let $\bar{z}^{j}$ be the value for $z_{t}=\left(i_{g, t}, b_{g, t}, a_{t}\right)$ if the $j$ th state occurs in period $t$. Assume further that $z_{t}$ takes on $n$ possible values and denote the transition matrix by $\pi$. In this case, the decision rules for consumption, investment, and hours are indexed by the state and defined on $\mathbb{R}^{2}$, e.g. $c^{j}\left(k_{t}, k_{g, t}\right), j=1, \ldots n$. The algorithm used to compute the decision functions is described in the Appendix A.

To simulate the model, we also need to specify the conditional means and transition probabilities for government investment, government consumption, and military hours. Unfortunately, in the case of the exogenous state variables, we have very few observations and a large number of parameters to identify. Our strategy is to choose a specification that reproduces the magnitude and timing of $b_{g, t}, i_{g, t}$, and $a_{t}$ during World War II for the U.S. and U.K. For the U.S. during World War II, we assume that the vector of exogenous variables $(z)$ takes on seven possible values (i.e., $n=7$ ). The seven vectors are chosen by matching realizations of $i_{g, t} / y_{t}, b_{g, t} / y_{t}$, and $a_{t} / h_{t}$ in the model with observations in the U.S. between 1939 and 1945. In Figure 4a, we plot these ratios for the U.S. during World War II. To make the ratios in the data and the model comparable, we subtract compensation of government employees, net exports, and inventories from GNP when constructing $y_{t}$. To construct $b_{g, t}$, we take total government purchases and subtract the compensation of government employees. Government investment is constructed from GOPO capital stock using (4). ${ }^{9}$ The year 1939 is assumed to be peacetime. Between 1938 and 1939, there was

9 Emp-mil and H, which are defined in the data appendix, are used to construct the ratio of military 
little, if any, preparation for war in the United States. Once the war began in Europe, the U.S. began investing in privately operated projects and increasing the number of troops. At that point, the involvement of the U.S. was still uncertain. By 1941, the level of investment of the government in projects operated by the private sector was one-third of its peak level. On the other hand, in 1941, the share of government consumption in output, $\left(b_{g} / y\right)$, was at its 1939 level. At the end of 1941, the U.S. declared war and non-GOPO government expenditures and conscription rose significantly. By 1943, the fraction of output used for GOPO investment had hit its peak while other expenditures continued to rise. The pattern of military hours relative to private hours is similar to that of government consumption. Both lag government investment and both are high at the end of the war. It is this pattern that we model when specifying the exogenous processes.

Our assumption about the timing of government expenditures and conscription is important. From the perspective of the private sector, government investment is a signal of future increases in conscription and future increases in government expenditures. In effect, it is a signal of future taxes. The private sector, seeing government investment increasing today updates its forecast for the likelihood of war and, therefore, for the likelihood of a large fiscal shock. Their response to this government investment and expected future spending is an increase in hours of work and, in some cases, an increase in private investment. ${ }^{10}$ The increase in hours of work leads to an immediate fall in labor productivity since capital cannot adjust immediately. However, if a sufficiently large increase in government expenditures is projected, the total capital stock increases. The increase in capital can lead to a rise in productivity in the period following the increase in government investment. The increase in capital can, therefore, produce a positive correlation between government consumption and labor productivity. Conscription can also increase labor productivity. An increase in conscription leads to a decrease in private hours of work and, therefore. increases labor productivity.

To parameterize the Markov chain for the British experiment, we again assume that the vector of exogenous variables $(z)$ takes on seven possible values. The war in Europe started two years earlier than in the U.S. but the changes in government investment. government consumption, and military hours during 1944 and 1945 were relatively small in Britain. Thus, to economize on parameters, we assume that these two periods represent

hours to private hours of work.

10 We will later show that increases in private investment can occur even if private and public capital are perfectly substitutable. 
the same state for the Markov chain. In Figure $4 \mathrm{~b}$, we plot the ratios $i_{g, t} / y_{t}, b_{g, t} / y_{t}$, and $a_{t} / h_{t}$ for Britain for the years 1938-1945. To construct $y_{t}$, we subtract the compensation of military employees, net exports, and inventories from GDP. To construct $b_{g, t}$, we take total government expenditures and subtract the compensation of military employees and Ashworth's [1953] measure of government investment $\left(i_{g, t}\right)$. The year 1938 is assumed to be peacetime. In 1939, they start investing in some projects but not to the extent that the U.S. had been investing before it entered the war. However, as in the U.S. there was little change in other government expenditures before the war. The largest increases in government consumption and conscription occurred after the British declared war. The pattern of shocks that we see for Britain is very similar to that of the U.S. At the midpoint of the war, the fraction of output used for government investment hit its peak while other expenditures and conscription continued to rise. Government consumption and military hours lag government investment but are high at the end of the war when government investment is low.

In Table 5, we report the conditional means and transition probabilities for government investment $\left(i_{g}\right)$, government consumption $\left(b_{g}\right)$, and the fraction of time in the military $(a)$ for our two experiments. These values of the three exogenous shocks imply that the ratios of government expenditures to output, $i_{g, t} / y_{t}$ and $b_{g, t} / y_{t}$, and military hours to private hours, $a_{t} / h_{t}$, for the model are equal to those in the data if we observe a war with the same pattern and duration as World War II. We choose the transition probabilities so that the ergodic probability of state 1 (peace) is $0 . \times 2$. Thus, if the duration of war, including periods for preparation, is on average 6 years. there would be 3 wars per century. The probability for being in each of the other statin is approximately equal to 0.03 . The only difference between the U.S. and the U.K. is $11_{1}$. w witication of $\pi_{71}$ and $\pi_{77}$. We increased the likelihood of being in state 7 since we as -111, , hat both 1944 and 1945 constitute state 7 for the U.K.

In Figure 5, we plot ratios of consumption. investment, and spending to output for the U.S. and the model. The U.S.ratios for 1937 through 1968 are in the top panel (Figure $5 a)$. In Figure 5b, we display a simulated war of the magnitude and duration of World War II. This simulation is based on the parameters of equation (5) and Table 5. Although we report only one realization, any war with the same duration and sequence of states would exhibit the same pattern shown in Figure 5b. As in the U.S. series, we find that increases in government consumption and investment crowd out private consumption and 
investment and increase output. However, relative to the U.S. the model's prediction of the decline in the ratio of consumption to output is too small. The result is due to the fact that the predicted rise in output is too small. U.S. output was 17 percent above trend at its peak in 1943 and 1944. The peak of output in the simulations occurs in state 4 . State 4 corresponds to 1942 when output in the U.S. was 12 percent above trend. In the simulations, output is only 9 percent above trend in state 4 . What drives the increase in. output in the model? In our model, both hours and the total capital stock are increasing. In Figure 5, we observe a rise in private investment in 1940 (or state 2). This increase leads to an increase in the capital stock in the following year. In 1941 and 1942, total investment is still high due to increases in government investment. Significant declines in the total capital stock do not occur until 1944 or 1945 (i.e., states 6 and 7). Hours growth, on the other hand is rapid from 1939 to 1940 but then stops as conscription picks up. This suggests that the problem is not the response in capital but the response in hours. Theory predicts that hours rise in response to expectations of large fiscal shocks. However, because we assume that hours must be used for the military, expected increases in military service at the end of the war lead the private sector to increase hours of production in the initial periods when conscription is low.

The simulations for Britain show a pattern in the shares of consumption and investment that is similar to that of Figure 5b. In particular, the low point in the consumption to output ratio occurs too early. However, for the British experiment, we come close to matching the maximum response of output to the wartime shocks. The model predicts that in state 3 (1940) that output is 16 percent above its peacetime level. In 1940, output in the data was 15 percent above trend. In 1941, output in the data reached its peak at 17 percent above trend. Because of the large increase in output we see a large decline in the consumption to output ratio. In the data, this ratio falls 39 percent and in the model it falls 33 percent.

The simulation displayed in Figure $5 \mathrm{c}$ assumes that the capital stocks are not perfectly substitutable $(\rho=.5)$. For values of $\rho$ less than 1 , we find a larger increase in output during war. This is not surprising given the fact that an increase in $i_{g}$ leads to high returns in subsequent periods and, therefore, larger responses in hours of work. What we do find surprising is that the consumption and investment ratios are in much better agreement with the data than in the case of perfect substitutes. In Figure 5c, we plot these ratios for the parameterization of (5) and Table 5 with $\rho=0.5$ instead of $\rho=1$. In addition, we set 
$\theta=\frac{1}{3}$ and reset the parameters of Table 5 so as to maintain the same steady state ratios for $c_{t} / y_{t}$ and $i_{t} / y_{t}$ and the same realizations of $i_{g, t} / y_{t}$ and $b_{g, t} / y_{t}$. The ratio of consumption to output does not hit its low point too early and falls to about the same level as that observed in the data. More importantly we do not see a negative ratio of private investment to output. However, a choice of $\rho<1$, or imperfect substitutability, may have problems if our model is to be used for predicting the effects of fiscal shocks during peacetime. During peacetime, the stock of government capital, $k_{g}$, is small. If $\rho<1$, the marginal product can be very high but depends on the value of $b$. Unless we assume that the government ignores the fact that it could achieve a high return from subsidizing investment, this choice of technology does not make much sense. But the results do suggest that some technological distinction between public and private capital may be warranted.

In Table 6, we report the time paths of hours and productivity for the U.S. and U.K. experiments. Both experiments use the parameters of (5) and Table 5. First consider the results for the U.S. As we noted earlier, hours rise in the first few periods of the war but fall once conscription increases significantly. If we compare this column to "Manhours per capita" in Table 2, we see a similar rise between 1939 and 1941 in the model and the data. However, after 1942, hours rise in the data and fall in the model. For productivity, we find good agreement between the model and data during the war. Notice that the simulation captures the 8 percent increase in productivity found in the data between 1941 and 1944 . Recall that Table 2 reports labor productivity for the U.S. for World War II. Furthermore, the model's predictions for labor productivity also compare favorably with the data on real wages. Both decline early and then rise strongly at the end of the war. Note, however, that an increase in labor productivity implies a decrease in capital productivity when technology shocks are absent. A declining marginal product of capital can explain the fall in stock market returns observed during the later part of World War II but cannot account for the decrease in the capital-output ratio.

Our U.K. simulation produces a much larger increase in hours of work than in the U.S. simulation. This explains why we see a larger increase in output in the U.K. experiment than in the U.S. experiment. In other respects, the pattern of hours is similar in the two countries: a sharp rise followed by a steady decline. There is a slight increase in hours of work for the U.K. at the end of the simulation but this increase is due to the fact that 1944 and 1945 are assumed to be the same state when calculating the Markov Chain. If an 8 th state is added for 1945 , then the predicted increase disappears. Note that much of 
the decline in hours for the two countries is due to conscription. Average weekly hours for the U.K. are reported in Table 1 for 1938 and 1943 through 1945. As in the simulation, we see a decline in hours at the end of the war with hours of work in 1938 at about the same level as in 1945. The pattern of productivity in the U.K. simulation is similar to that of the U.S. Productivity falls initially as hours of work rise and capital fixed. As the capital stock increases, labor productivity rises. Thus, we find productivity positively correlated with government expenditures in both countries.

To see if these results are robust to changes in the parameterization of (5) and Table 5, we tried some alternative specifications. Consider first the parameters of preferences. For the weight on consumption in utility, we use $\frac{1}{4}$. If we increase $\gamma$ to $\frac{1}{3}$, the value used by Kydland and Prescott, we find a larger steady state value for hours of work but a similar pattern in the response of hours to the shocks during the war. With a larger value of hours in the steady state, it is necessary to increase the values of $a$ in the Markov chain. Then the increase in military hours produces a larger decline in hours towards the end of the war. The value of $\omega$ chosen for our experiments is 1 . To significantly change our results, we must assume either that agents are very risk averse ( $\omega$ large) or risk neutral ( $\omega$ close to 0 ). For most values used in the business cycle literature, we do not find much of a difference from what we report above. The discount factor, which we set at 0.96 , affects the consumption versus saving decision. When we change this parameter we find differences in the steady state values but little difference in the responses to shocks.

Consider next the parameters of technology: As we noted above, the choice of $\rho$ significantly affects our results. We use $\rho=1$ hecause we want a theory of the effects of government purchases that can be applied in luth peacetime and wartime. However, improvements in the responses of consumptim and investment suggest that alternative specifications of technology should be explorinl. Fir the share of capital in income, we use $1 / 4$. If we increase the value of this paramet er. w. increase the level of investment in periods of peace but we do not find a significant reduction in the response of investment to fiscal shocks. Finally, consider changes in the transition probabilities. To significantly affect our results, we would need to choose values for $\pi$ that imply very different ergodic distributions. Our current specification assumes that most of the time is spent in peacetime. If we increase the time spent in any of the pre-war or war periods, we change the decision functions but we also simulate wars that last too long from a historical standpoint.

In summary, we have presented a simple model which we use to quantify the effects 
of changes in government investment, government consumption, and military hours. We have shown that, although the model abstracts from shocks to technology and to taxes, the model does capture a significant fraction of the movement of GNP and its components, hours of work, and productivity. We have also shown that it is not necessary to include imperfectly competitive markets to get a positive correlation between productivity and government expenditures. But it is important to distinguish the uses of government expenditures and the timing of different expenditures during the war. Finally, we have shown that our theory can more easily account for observations of the labor market in Britain than in the U.S. With all agents forced to put time into the military, we find a significant decline in hours in periods when the rate of conscription is high. In the U.S. during World War II, we saw large increases in both private and military hours. In Appendix B, we explore an extension of this model which distinguishes civilian and noncivilian employment as well as variations in hours of work and employment.

\section{Conclusions}

In this paper we have documented the responses of the British and U.S. economies to the two World Wars and proposed a simple model for that allows us to quantify the roles of government investment, conscription and government consumption. Our model captures a significant fraction of the movement in GNP and its components and is consistent with the U.S. observations of rising hours and average productivity. We find further that the British experience of declining employment and increasing productivity can be explained by Britain's high conscription rates.

There are a number of features of the data that the model cannot explain. Both countries exhibited large increases in hours per worker during World War II yet, the pattern of employment differed in the two countries. Our model makes no distinction between these two margins. In addition, our model predicts that an increase in government purchases has opposite effects on the output-capital ratio and labor productivity. Thus, it is difficult for our model to reconcile the large increase in the capital output ratio and concurrent decline in interest rates that occurred in the U.S. during World War II.

In Section 2 of our paper we found that variations in capacity utilization had an important effect on the properties of Solow's residual. In Appendix B we explore some of the consequences of modeling capacity utilization in a competitive framework.

Our analysis raises other questions as well. For instance, does the large buildup

of GOPO capital that occurred during the war have implications for peacetime as well? 
Between 1939 and 1945 the output- capital ratio increased by a third (see for instance, Blanchard and Fischer [1989]). Since the war this ratio has remained relatively stable. The increase in GOPO capital during the war certainly offers a partial explanation for the large increase in the capital output ratio between 1939-45. But, why has the output capital ratio not fallen back to its prewar level in the postwar period as the stock of GOPO capital has fallen? The Cold War has resulted in continuing GOPO investment in the postwar period but, the magnitude of this investment has been small. In Figure 2 we can see that by 1955 GOPO capital constituted less than 10 percent of the total capital stock in manufacturing. To explain the stability of the capital output ratio in the postwar period requires us to look beyond GOPO capital. Aschauer [1993] and Gordon [1969] have argued that other forms of government investment like infrastructure are important for understanding growth in the postwar period. The postwar transition from privately operated railways to a public highway system and air transit system with government owned airports may be one plausible explanation for the fact that the output capital ratio has remained high in the postwar period.

Changes in participation rates may offer an alternative explanation for the high capital-output ratio. During the Second World War participation rates of wome:. increased rapidly. After the war many women remained in the workforce. Participation rates of women rose by 60 percent between 1930 and 1950 with most of this increase oc-

curring during and after World War II. Higher participation rates may have resulted in a more intensive use of capital in the postwar period.

\section{Data Appendix}

1. British data sources.

- GDP: Gross Domestic product in constant 1980 prices, per capita. The source for this times series is Mitchell [1988], pp. 831-841: GDP at market prices, current prices and GDP at market prices constant prices various base years. The population measure is described below. Note that between 1910-1920 GDP and its components include Ireland, after 1920 they exclude the Republic of Ireland.

- C: Consumers' Expenditure in constant 1980 prices, per capita from Mitchell [1988], pp. 831-841.

- I: Gross Domestic Fixed Capital Formation in constant 1980 prices, per capita from Mitchell [1988], pp. 831-841.

- Netx: Exports less Imports in constant 1980 prices, per capita from Mitchell [1988], pp. 831-841.

- Gov: Public Authorities' current expenditures on goods and services in constant 1980 prices, per capita from Mitchell [1988], pp. 831-841.

- Mil: Gross Public Expenditure of the United Kingdom on army and navy and air force plus votes of credit during the war years deflated by the GDP-deflator, per capita from Mitchell [1988], pp. 587-594. 
- Exp: Gross Public Expenditure of the United Kingdom deflated by the GDPdeflator, per capita from Mitchell [1988], pp. 587-594.

- Rev: Total Gross Public Income of the United Kingdom deflated by the GDPdeflator, per capita from Mitchell [1988], pp. 587-594.

- Emp: Total civilian employment, per capita from Feinstein [1972], pp. T126T127.

- Emp-Mil: Armed Forces, per capita from Feinstein [1972], pp. T126-T127.

- GDP/Emp: Output Per worker from Feinstein [1972], pp. T52-T53. The numerator is Feinstein's GDP-compromise constant factor cost estimate and the denominator is total civilian employment plus armed forces.

- Wage: Index of weekly wage rates, divided by the Labor Gazette's retail price index from Feinstein [1972], T140-T141.

- RR-long: Yield on 2.5 percent Consols Mitchell [1988], p. 678, deflated using the GDP deflator from Mitchell [1988].

- Population: Estimated Mid-Year Home Population for England and Wales plus Scotland plus Ireland through 1920. For 1921 through 1965 population is for England and Wales, Scotland and Northern Ireland. The source is Mitchell [1988], pp. 13-14.

2. U.S. Data Sources ${ }^{11}$

- GNP: Gross National Product in 1982 constant dollars per capita. From 19101928 the source is Romer [1989]. For 1929-1969, the source is National Income and Product Accounts 1929-1982.

- C: Consumer expenditures in 1982 constant dollars per capita. From 1910-1928 the source is Romer [1987], Table 3. From 1929-1969 the source is the NIPA.

- I: Fixed Investment in 1982 constant dollars per capita. From 1910-1928 the source is Romer [1987], Table 3. From 1929-1969 the source is the NIPA.

- Netx: Net Exports in 1982 constant dollars per capita. From 1910-1928 the fraction of net exports in 1929 constant dollar GNP as reported in Kendrick [1961]. pp. 293-297, was applied to Romer's GNP time series to produces estimates of constant dollar net exports.

- Gov: Government purchases of goods and services in constant 1982 dollars, per capita. From 1910-1928 the source is Romer [1987], Table 3. From 1929-1969 the source is the NIPA.

- GOPO capital and private capital reported in Figure 4 are gross stocks of equipment and structures in manufacturing and government owned gross stocks of equipment and structures in manufacturing from Wasson, Musgrave and Harkins in Survey of Current Business [1970] expressed in 1958 constant dollars. For some of the model simulations we needed 1982 constant dollar estimates of GOPO. These were calculated by expressing total net GOPO capital (all industries) as a fraction of 1958 dollar net total private capital (all industries). Then this frac:tion was applied to 1982 constant dollar estimates of net total private capital (all industries) in Fixed Reproducible Tangible Wealth in the U.S., 1925-1985 (Dept. of Commerce) to produce 1982 constant dollar estimates.

- Mil: Military outlays of the federal gov.t on the army, navy and air force, in constant 1982 dollars, per capita. Current doliar figures are from Historical Statistic's

11 The data used in this paper were made available in part by the Inter-University Consortium for Political and Social Research. The data were originally collected by the NBER. 
of the U.S., series Y-458:60. These were converted to constant dollar values by deflating by the GNP deflator.

- Gexp: U.S. Federal Government expenditures from Historical Statistics of the U.S. [1975], series Y336 and Y457, converted into constant dollars by deflating using the GNP deflator, per capita.

- Grev: U.S. Federal Government Revenues from Historical Statistics of the U.S. [1975], series Y336 and Y457, converted into constant dollars by deflating using the GNP deflator, per capita series Y335,y339,y343.

- H: Total Manhours from Kendrick as reported in Long Term Economic Growth [1973]. Dept. of Commerce p. 1141 divided by population over 16. This series is reported as an index with a 1958 base. The index was scaled by hours worked in 1958 in private industries from NIPA 1929-1982 [1986] p. 287 to convert its units into billions of hours.

- N: Labor input from Kendrick as reported in Long Term Economic Growth [1973], Dept. of Commerce p. 1141 divided by population over 16 This series is reported as an index with a 1958 base. The index was scaled by hours worked in 1958 in private industries from NIPA 1929-1982 [1986] p. 287 to convert its units into billions of hours.

- Emp-mil: Military personnel on active duty from Historical Statistics of the U.S. [1975], series Y904, converted into an hours measure assuming annual hours worked are 2500 , per capita.

- GNP/H: Labor Productivity measured using manhours.

- GNP/N: Labor Productivity measured using labor input.

- Wage: Real wages in manufacturing. From 1910-1919 they are measured using payroll average hourly earnings in manufacturing from Historical Statistics of the U.S., p. 168. The 1920 observation is the average of this time series and average hourly earnings in all manufacturing industries p. 170. From 1921-1969 the p. 170 average hourly earnings numbers are used. Real wages are then calculated by deflating by the CPI all-items as reported in Historical Statistics of the U.S., p. 211.

- RR-short: Yield on commercial paper from NBER tape, deflated using the GDP deflator.

- RR-long: Moody's AAA bond yields from NBER tape series number a13108, deflated using the GDP deflator.

- Population: U.S. population over 16 from Historical Statistics of the U.S. [1975], p.10. The observations 1917-1919 have been augmented with armed forces (p.1141 in Colonial Statistics) using $0.53 \times(\mathrm{M}-\mathrm{emp}(\mathrm{t})+\mathrm{pop}(\mathrm{t}))$ to account for the fact that the pop dataset does not include forces overseas during World War I. The fraction 0.53 is reported in Colonial Statistics p. 1140 as the average fraction of armed forces overseas during World War I.

\section{Appendix A}

In Section 3, we defined an equilibrium to be decision functions that maximize households' utility subject to certain resource constraints. In this Appendix, we describe the algorithm used to compute the equilibrium decision functions. ${ }^{12}$ The general formulation

12 A more detailed technical appendix is available upon request. 
of our problem is as follows: find $G: \Omega \subset \mathbb{R}^{n} \rightarrow \mathbb{R}^{m}$ that satisfies

$$
F(G ; \mathbf{x})=0
$$

where $F: \Psi_{1} \rightarrow \Psi_{2}, \Psi_{j}, j=1,2$ are function spaces, and $\mathbf{x}$ is an $n$-dimensional vector and is some point in $\Omega$. In our case, the function $G$ is the vector of consumption functions which are indexed by the state of the Markov chain governing exogenous states. The first element of the vector $\mathbf{x}$ is private capital and the second is public capital. The mapping $F$ is the first-order necessary condition that relates current marginal utility to the expectation of the marginal utility next period weighted by the return from holding capital. Given the consumption function, the remaining first-order conditions can be used to determine the hours and investment decision functions.

Thus, we are looking for $m$ functions that (approximately) satisfy a set of functional equations. To do this, we apply a finite element method with piecewise linear shape functions. Define the approximation to $G$, namely $G^{h}(\mathbf{x})$, as follows:

$$
G^{h}(\mathbf{x})=\sum_{a=1}^{\text {nnodes }} \gamma_{a} N_{a}(\mathbf{x})
$$

where $\gamma_{a}, a=1, \ldots$, nnodes is a vector of constants and $N_{a}(\mathbf{x}), \mathbf{x}=(x, y)$ for the 2dimensional case is given by the hat-shaped functions,

$$
N_{a}(\mathbf{x})= \begin{cases}\frac{x-x_{a-1}}{x_{a}-x_{a-1}} \cdot \frac{y-y_{a-1}}{y_{a}-y_{a-1}} & x_{a-1} \leq x \leq x_{a}, y_{a-1} \leq y \leq y_{a} \\ \frac{x_{a+1}-x}{x_{a+1}-x_{a}} \cdot \frac{y-y_{a-1}}{y_{a}-y_{a-1}} & x_{a} \leq x \leq x_{a+1}, y_{a-1} \leq y \leq y_{a} \\ \frac{x-x_{a-1}}{x_{a}-x_{a-1}} \cdot \frac{y_{a+1}-y}{y_{a+1}-y_{a}} & x_{a-1} \leq x \leq x_{a}, y_{a} \leq y \leq y_{a+1} \\ \frac{x_{a+1}-x}{x_{a+1}-x_{a}} \cdot \frac{y_{a+1}-y}{y_{a+1}-y_{a}} & x_{a} \leq x \leq x_{a+1}, y_{a} \leq y \leq y_{a+1} \\ 0 & \text { elsewhere, }\end{cases}
$$

which are equal to 1 at each node $a$. The constants, $\gamma_{a}$, are chosen to satisfy the following equations

$$
H(\gamma)=\int_{\Omega} F\left(G^{h}(\mathbf{x}) ; \mathbf{x}\right) N_{a}(\mathbf{x}) d \mathbf{x}=0, \quad a=1, \ldots, \text { nnodes }
$$

where $\gamma=\left[\gamma_{1}^{\prime}, \ldots, \gamma_{n n o d e s}^{\prime}\right]^{\prime}$ is a vector of length $m *$ nnodes and $H$ has $m * n$ nodes elements. Equation (A.1) is the weak formulation of our problem.

The main computational task is to find $\gamma$ such that $H(\gamma)=0$. If we use a NewtonRaphson algorithm to find $\gamma$, then we choose some initial guess, say $\gamma^{0}$, and iterate as follows:

$$
\gamma^{k+1}=\gamma^{k}-J\left(\gamma^{k}\right)^{-1} H\left(\gamma^{k}\right)
$$


where $J$ is the Jacobian of $H$. Since $G^{h}\left(x_{a}\right)=\gamma_{a}$ where $a$ is some node on the grid, starting guesses can easily be obtained. For the examples of Section 3 , we started with an increasing, linear function which is equal to steady state consumption when evaluated at the steady state values of private and public capital. Note that the Newton iterations require algorithms for solving linear systems, $A u=b$, where $A=J\left(\gamma^{k}\right), b=H\left(\gamma^{k}\right)$. For large $n$ or nnodes, $A$ is a large, sparse matrix; in such cases, we use an iterative method to solve the linear system.

\section{Appendix B}

In Section 2 we calculated Solow's residual for a production technology that included government capital and variation in capacity utilization. We found that, once we accounted for changes in government capital and changes in utilization, the growth in total factor productivity during World War II was equal to its average postwar rate. In Section 3, we described a model that explores the effects of changes in government investment. In this Appendix, we describe a model that allows for variation in the workweek of capital as well as variations in government capital. ${ }^{13}$

Assume that there are a large number of ex-ante identical agents with preferences

$$
E \sum_{t=0}^{\infty} \beta^{t} u\left(c_{t}, \ell_{t}\right), \quad u(c, \ell)=\frac{\left(c^{\gamma} \ell^{1-\gamma}\right)^{1-\omega}-1}{1-\omega}, 0 \leq \beta, \gamma \leq 1, \omega>0
$$

where $c_{t}$ is consumption at date $t, \ell_{t}$ is leisure at date $t$, and $h_{t}=1-\ell_{t}$ is hours spent working at date $t$. An agent that works $h_{t}$ hours with $k_{\mathrm{t}}$ units of private capital and $k_{g, t}$ units of public capital produces a homogeneous good, $y_{t}$, with the following production technology:

$$
y_{t}=\lambda\left\{k_{t}+k_{g, t}\right\}^{\theta} h_{t} .
$$

The good can be consumed or invested, e.g., $c_{t}+i_{t}+i_{g, t}+b_{g, t} \leq y_{t}$. In specifying the production technology, we assume that private and public capital are perfect substitutes.

Note that the production technology exhibits increasing returns to scale. However. if we assume that agents buy and sell lotteries over bundles of goods, hours, and capital. as in Prescott and Townsend [1984], then we can convexify the commodity space. Suppose that agents, in date 0 , enter into contracts which specify the number of hours to work and the number of units of capital to provide. In return for hours and capital, the agents receive

13 The model is similar to that of Kydland and Prescott [1991]. We include conscription, government investment, and heterogeneity in preferences over agents' employment status but ignore moving costs. 
consumption goods. To compute their equilibrium decisions, we can exploit the fact that the competitive equilibrium is Pareto optimal and solve the social planner's problem:

$$
\max _{\left\{c_{1, t}, c_{0, t}, h_{t}, n_{t}\right\}} E \sum_{t=0}^{\infty} \beta^{t}\left\{n_{t} u\left(c_{1, t}, 1-h_{t}\right)+\left(1-n_{t}\right) u\left(c_{0, t}, 1\right)\right\}\left(1-a_{t}\right)
$$

subject to

$$
n_{t} c_{1, t}+\left(1-n_{t}\right) c_{0, t}+i_{t}+i_{g, t}+b_{g, t} \leq \lambda\left(\frac{k_{t}+k_{g, t}}{n_{t}}\right)^{\theta} h_{t} n_{t}
$$

and subject to the constraints on capital, i.e., equation (4) of Section 3 , where $c_{1}$ is consumption of those working in the private sector, $c_{0}$ is consumption of those not working, $i$ is private investment, $i_{g}$ is government investment, $b_{g}$ is government consumption, $k$ is private capital, $k_{g}$ is government capital, $a$ is the fraction of the population in the military, $n$ is the fraction of civilian the population employed in the civilian sector, and $h$ is the number of hours that the plant is operated. The terms of the resource constraint are per capita.

In posing the planner's problem, we have imposed some restrictions. Hornstein and Prescott [1993] show that for the class of problems that includes ours, the equilibrium consumption vector places mass on only two points. The first has zero hours and zero units of capital, and the agent receives $c_{0}$ consumption goods. The second has a positive value for hours and capital and the agent receives $c_{1}$ consumption goods. Thus, we need not search over all possible lotteries. To compute an equilibrium, we again use the procedure outlined in the Appendix A. In this case, we find a function for consumption of the fraction working, $c_{1, t}$. The consumption function is chosen to approximately satisfy the intertemporal first order condition of the maximization problem. The remaining functions are derived from the intratemporal first order conditions and the whlution for the consumption function of the working agents.

One advantage of this model over that it ciction 3 is that it allows us to explore the role of capacity utilization. In Section 3. we assumed that the only way to increase current output was to change the number of hours that the stand-in consumer worked. In the environment described here, both hours per worker and the number of workers can be varied. During war, we observe large changes in both margins. In addition, during wars we see the output-capital ratio rising at the same time average productivity rises. Our previous specification was inconsistent with this fact. With variations in capacity utilization, both average products may rise concurrently. Another advantage of this model is its differential treatment of workers in the military and the private sector. Since all 
agents in Section 3 are ex-post identical, we assume that the representative agent spends some fraction of his time in production, some fraction of his time in the military, and some fraction of his time in leisure activities. We do not distinguish civilian and noncivilian employment. As a result, we find that the hours of work decision was very sensitive to the rate of conscription since hours of work in the private sector and hours of work in the military have the same effect on utility.

In the course of analyzing this model we have uncovered the following peculiar property. In equilibrium, hours of work do not vary over time. To see this, consider the first-order necessary conditions for consumption, employment, and hours of work:

$$
\begin{aligned}
& \frac{\partial u\left(c_{0, t}, 1\right)}{\partial c_{0, t}}=\frac{\partial u\left(c_{1, t}, 1-h_{t}\right)}{\partial c_{1, t}} \\
& n_{t} \frac{\partial u\left(c_{1, t}, 1-h_{t}\right)}{\partial \ell_{t}}=\frac{\partial u\left(c_{1, t}, 1-h_{t}\right)}{\partial c_{1, t}} \lambda\left(k_{t}+k_{g, t}\right)^{\theta} n_{t}^{1-\theta} \\
& u\left(c_{1, t}, 1-h_{t}\right)-u\left(c_{0, t}, 1\right)=\frac{\partial u\left(c_{1, t}, 1-h_{t}\right)}{\partial c_{1, t}}\left(c_{1, t}-c_{0, t}-(1-\theta) \lambda\left(k_{t}+k_{g, t}\right)^{\theta} n_{t}^{-\theta} h_{t}\right.
\end{aligned}
$$

The first condition equates the marginal utilities of the two types of agents. The second condition equates the ratio of the marginal utility of leisure of the working agent to the marginal benefit of running the plant an extra hour. The third condition equates the change in welfare due to one more person working to the additional output produced by having an additional employee. With some manipulation of these three equations we have the following condition:

$$
\psi\left(1-h_{t}\right) \frac{\left\{\left(1-h_{t}\right)^{\psi}\right\}^{1-\omega}-1}{1-\omega}=(1-\theta) h_{t}, \quad \psi=\frac{\gamma(1-\omega)-1}{1-\gamma}
$$

Notice that this formula involves only $h_{t}$ and the parameters of the utility and production functions. Therefore, $h_{t}$ must be constant in equilibrium. Furthermore, there are only two fixed points of equation (B.1), $h_{t}=0$ and $0<h_{t}<1$. This follows from the fact that the left hand side of the equation is a concave function that is equal to 0 if $h_{t}=0,1$ if $h_{t}=1$ and has a derivative equal to 1 at 0 . If $0<\theta<1$, then the right hand side has a slope that is between 0 and 1 . Therefore, the linear function $(1-\theta) h_{t}$ crosses the concave function twice, once at 0 and once at some point in $(0,1)$. We can exclude the $h_{t}=0$ outcome since it is not an optimum. Therefore, to calculate the equilibrium hours decision, we find the positive fixed point of equation (B.1).

The prediction that hours per worker are constant is at odds with the data. At the aggregate level, hours per worker rose 20 percent between 1939 and 1942. Large increases 
were observed in many industries. For example, the average hours worked per week in the machine tools industry rose 22.6 percent between 1939 and $1942 .{ }^{14}$ Thus, while this model can account for the growth in total factor productivity during World War II, its predictions for hours per worker do not match up with the observations in the data.

One way of resolving this problem is to allow for differential costs of entering the labor force. It is unlikely that the disutility of a woman with six children who enters the labor force is equal to that of a woman with no children. Suppose that individual preferences are given by

$$
E \sum_{t=0}^{\infty} u\left(c_{t}, 1-h_{t}\right)-\eta \chi_{\left\{h_{t}>0\right\}}
$$

where $\eta$ measures the disutility of entering the workforce and $\chi$ is an indicator function. If the utility costs of entering the workforce vary, $\eta$ will have a nondegenerate distribution. If civilians are aligned with points on the interval $[0,1-\mathrm{a}]$, then we can construct a cost function. For example, suppose that agents are aligned in such a way that costs are represented by a linear, increasing function. Then, in the aggregate, the costs of increasing employment are given by

$$
-(1-a) \int_{0}^{n}\left(\xi_{0}+2 \xi_{1} s\right) d s=-(1-a)\left\{\xi_{0} n+\xi_{1} n^{2}\right\}, \quad \xi_{1}>0
$$

where $a$ is the fraction of people in the military and $n$ is the fraction of civilians who work. If preferences are redefined with this additional term, it is no longer true that hours per week remain fixed in response to large fiscal shocks. If the costs of increasing employment are high, it may be optimal to vary hours. The magnitude of costs required to produce plausible variation in hours per worker is an open question.

14 See the December 1942 issue of the Survey of Current Business for average hours in other industries. 


\section{References}

Aiyagari, Rao, Lawrence Christiano, and Martin Eichenbaum. 1992. "The output, em- ployment, and interest rate effects of government consumption," Journal of Monetary Economics.

Aschauer, David A. 1993. "Public capital and economic growth," The Jerome Levy Economics Institute Public Policy Brief.

Ashworth, William. 1953. Contracts and Finance. London: Her Majesty's Stationery Office.

Barro, Robert J. 1981. "Output effects of government purchases." In Journal of Political Economy, 89:1086-1121.

Baxter, Marianne, and Robert G. King. 1990. "Fiscal policy in general equilibrium." Working Paper 244, University of Rochester.

Blanchard, Olivier J. and Fischer, Stanley. 1989. Lectures on macroeconomics. Cambridge: MIT Press.

Bowley, Arthur L. 1921. Prices and Wages in the United Kingdom, 1914-1920. London: Oxford University Press.

Bry, Gerhard. 1960. Wages in Germany 1871-1945. Princeton: Princeton University Press.

Christiano, Lawrence C. 1988. "Why dos inventory investment fluctuate so much?" Journal of Monetary Economics, 21: 247-280.

Cook, James Allan. 1948. The marketing of surplus war property. Washington, D.C.: Public Affairs Press.

Correia, Iasabel H., Neves, Joao L. and Rebelo, Sergio. 1992. "Business cycles from 1850-1950: new facts about old data." European Economic Review 36 (213): 459-467.

Crowell, J. Franklin. 1920. Government War Contracts. New York: Oxford University Press.

Gordon, Robert J. 1969. " $\$ 45$ billion of U.S. private investment has been mislaid." American Economic Review, LIX(3): 221-238.

Gordon, Robert J. 1970. Communications: "\$45 billion of U.S. private investment has been mislaid: Reply." American Economic Review LX(5): 940-945.

Feinstein, C. H. 1972. National Income, Expenditure and Output of the United Kingdom 1855-1965. Cambridge: Cambridge University Press.

Great Britain. Ministry of Munitions. 1918-1922. History of the Ministry of Munitions. London: His Majesty's Stationery Office.

Hall, Robert E. 1980. "Labor supply and therreate fluctuations" Carnegie- Rochester Series on Public Policy Vol. 12 Amsterilum. Virth Holland.

Hancock, W.K. 1951. Statistical Digest of the IIir. London: His Majesty's Stationary Office and Longmans Green and Co.

Hancock, W. K., and M. M. Gowing. 1949. Britısh War Economy. London: His Majesty's Stationery Office.

Homer, Sidney, and Richard Sylla. 1991. A History of Interest Rates. 3rd ed. New Brunswick: Rutgers University Press.

Hornstein, Andreas and Prescott, Edward C. 1993. "The plant and the firm in general equilibrium." forthcoming in General Equilibrium, Growth and Trade II. New York: Academic Press.

Hughes, Thomas J.R. 1987. The Finite Element Method. New Jersey: Prentice Hall.

Jaszi, George. 1970. "Communications: $\$ 45$ billion of U.S. private investment has been mislaid: Comment." American Economic Review, LX(5): 934-939. 
Kendrick, John W. 1961. Productivity Trends in the United States. Princeton: Princeton University Press.

Kendrick, John W. 1973. Postwar Productivity Trends in the United States. NewYork: National Bureau of Economic Research

Kuznets, Simon. 1945. National Product in Wartime. New York: National Bureau of Economic Research.

Kydland, F. and E. Prescott. 1982. "Time to Build and Aggregate Fluctuations," Econometrica 50: 1345-1370.

Kydland, F. and E. Prescott. 1991. "Hours and employment variation in business cycle theory," Economic Theory 1: 63-81

Maddison, Angus. 1989. The World Economy in the 20th Century. Paris: Organisation for Economic Co-Operation and Development.

Mankiw, N. Gregory. 1987. "Government Purchases and Real Interest Rates" Journal of Political Economy, 95:407-419.

Mitchell, Wesley C. 1919. History of Prices During the War. Washington, D.C.: Government Printing Office.

Mitchell, B. R. 1980. European Historical Statistics 1750-1975. 2nd rev. ed. New York: Facts on File.

Mitchell, B. R. 1988. British Historical Statistics. Cambridge: Cambridge University Press.

Noyes, Alexander D. 1926. The War Period of American Finance 1908-1925. New York: Knickerbocker Press.

Ohanian, Lee E. 1992. "The macroeconomic effects of war finance in the United States." Manuscript, University of Pennsylvania.

Ohanian, Lee E. 1993. "The effects of monetary policy during World War II: Price controls, rationing, and inflation." Ph.D. dissertation, Chapter 4.

Prescott, Edward C. and Townsend, Robert M. 1984. "Pareto optima and competitive equilibria with adverse selection and moral hazard." Econometrica, 52: 21-45.

Prescott, Edward C. 1986 "Theory ahead of business cycle measurement." CarnegieRochester Conference Series on Public Policy, 25: 11-44.

Rockoff, Hugh. 1984. Drastic Measures: A History of Wage and Price Controls in the United States. Cambridge: Cambridge University Press.

Romer, Christina D. 1987. "Gross national product, 1909-1928: Existing estimates, new estimates, and new interpretations of World War I and its aftermath." Working Paper 2187, National Bureau of Economic Research.

Romer, Christina D. 1989. "The prewar business cycle reconsidered: New estimates of gross national product, 1869-1908." Journal of Political Economy, 97:1-37.

Rotemberg, Julio J., and Michael Woodford. 1991. "Markups and the business cycle." In NBER macroeconomics annual 1991, Cambridge: MIT Press.

Rotemberg, Julio J., and Michael Woodford. 1992. "Oligopolistic pricing and the effects of aggregate demand on economy activity." Journal of Political Economy. 100(6): 1153-1207.

Saad, Youcef 1993, "Lecture Notes: Scientific Computation 8002" manuscript University of Minnesota.

U.S. Department of Commerce. Bureau of Foreign and Domestic Commerce. 1942-1946, 1956, 1970. Survey of Current Business. Washington, D.C.: U.S. Government Printing Office.

U.S. Department of Commerce. Bureau of Economic Analysis. 1973. Long Term Economic 
Growth 1860-1970. Washington, D.C.: U.S. Government Printing Office.

U.S. Department of Commerce. Bureau of the Census. 1975. Historical Statistics of the United States, Colonial times to 1970. Bicentennial ed., Part 2. Washington, D.C.: U.S. Government Printing Office.

U.S. Department of Commerce. Bureau of Economic Analysis. 1986. The National Income and Product Accounts of the United States, 1929-82. Washington, D.C.: U.S. Government Printing Office.

U.S. Department of Commerce. Bureau of Economic Analysis. 1987. Fixed Reproducible Tangible Wealth in the United States, 1925-85. Washington, D.C.: U.S. Government Printing Office.

Wasson, Robert C., John C. Musgrave, Claudia Harkins. 1970. "Alternative estimates of fixed business capital in the United States, 1925-1968." Survey of Current Business, 4: 18-36. Washington, D.C.: U.S. Government Printing Office. 
Table 1

Employment, Productivity and Wages

in Great Britain during World War I and World War II

\begin{tabular}{lccccc}
\hline \hline & & A. World War I & & \\
Year & $\begin{array}{c}\text { Civilian } \\
\text { Employment }^{\mathrm{a}}\end{array}$ & $\begin{array}{c}\text { Armed Forces }^{\mathrm{b}} \\
\text { (thousands) }^{\text {(thousands) }}\end{array}$ & $\begin{array}{c}\text { Unemployment } \\
\text { (th) }\end{array}$ & $\begin{array}{c}\text { Output per }_{\text {Worker }^{\mathrm{d}}} \\
(1913=100)\end{array}$ & $\begin{array}{c}\text { Real Wages }^{\mathrm{e}} \\
(1913=100)\end{array}$ \\
\hline 1913 & 19,910 & 400 & 2.1 & 100 & 100 \\
1914 & 19,440 & 810 & 3.3 & 101 & 100 \\
1915 & 18,400 & 2,490 & 1.1 & 106 & 89 \\
1916 & 17,700 & 3,500 & .4 & 107 & 83 \\
1917 & 17,100 & 4,250 & .6 & 107 & 80 \\
1918 & 17,060 & 4,430 & .8 & 107 & 90 \\
1919 & 19,030 & 2,130 & 3.4 & 97 & 102 \\
1920 & 20,810 & 760 & 2.0 & 92 & 105 \\
\hline
\end{tabular}

B. World War II

Civilian

\begin{tabular}{cccccc} 
Year & $\begin{array}{c}\text { Employment }^{\mathrm{a}} \\
\text { (thousands) }\end{array}$ & $\begin{array}{c}\text { Armed Forces }^{\mathrm{b}} \\
\text { (thousands) }\end{array}$ & $\begin{array}{c}\text { Average } \\
\text { Weekly Hours }^{\mathrm{f}}\end{array}$ & $\begin{array}{c}\text { per Worker }^{\mathrm{d}} \\
(1938=100)\end{array}$ & $\begin{array}{c}\text { Real Wages }^{\mathrm{e}} \\
(1938=100)\end{array}$ \\
\hline 1938 & 20,986 & 432 & 46.5 & 100 & 100 \\
1939 & 21,800 & 480 & - & 97 & 98 \\
1940 & 20,800 & 2,270 & - & 103 & 96 \\
1941 & 20,600 & 3,380 & - & 108 & 95 \\
1942 & 20,700 & 4,090 & - & 108 & 95 \\
1943 & 20,200 & 4,780 & 50.0 & 109 & 97 \\
1944 & 19,700 & 4,990 & 48.6 & 106 & 99 \\
1945 & 19,100 & 5,130 & 47.4 & 103 & 102 \\
\hline \hline
\end{tabular}

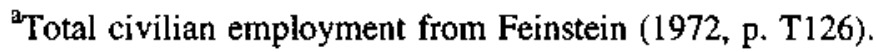

${ }^{b}$ Armed forces from Feinstein (1972, p. T126).

'Percentage unemployed from Feinstein (1972, p. T126).

${ }^{\mathrm{d}}$ The ratio of real GDP from Feinstein (1972) to civilian employment plus armed forces expressed as an index.

${ }^{\mathrm{e}}$ Index of weekly wage rates from Feinstein (1972, p. T140) divided by the Ministry of Labour Gazette index of retail prices, also from Feinstein (1972, p. T140).

${ }^{f}$ Average weekly hours, Hancock (1951, p. 204). 
Table 2

Employment, Hours, Productivity, and Wages

in the U.S. during World War I and World War II

\begin{tabular}{|c|c|c|c|c|c|}
\hline \multirow[b]{2}{*}{ Year } & \multicolumn{4}{|c|}{ A. World War I } & \multirow[b]{2}{*}{$\begin{array}{l}\text { Real Wages in } \\
\text { Manufacturing } \\
\quad(1913=100)\end{array}$} \\
\hline & $\begin{array}{c}\text { Persons } \\
\text { Engaged }^{\mathrm{a}} \\
\text { (thousands) }\end{array}$ & $\begin{array}{c}\text { Armed } \\
\text { Forces }^{\mathrm{b}} \\
\text { (thousands) }\end{array}$ & $\begin{array}{l}\text { Manhours } \\
\text { Per Capita } \\
(1913=100)\end{array}$ & $\begin{array}{c}\text { Labor } \\
\text { Productivity }^{d} \\
(1913=100)\end{array}$ & \\
\hline 1913 & 36,285 & 155 & 100 & 100 & 100 \\
\hline 1914 & 35,787 & 166 & 96 & 93 & 100 \\
\hline 1915 & 35,916 & 174 & 94 & 97 & 99 \\
\hline 1916 & 38,332 & 179 & 99 & 104 & 102 \\
\hline 1917 & 39,004 & 644 & 100 & 99 & 99 \\
\hline 1918 & 38,938 & 2,897 & 98 & 107 & 103 \\
\hline 1919 & 38,990 & 1,173 & 94 & 114 & 107 \\
\hline 1920 & 39,183 & 343 & 95 & 113 & 115 \\
\hline
\end{tabular}

B. World War II

\begin{tabular}{|c|c|c|c|c|c|}
\hline Year & $\begin{array}{c}\text { Persons } \\
\text { Engaged }^{\mathrm{a}} \\
\text { (thousands) }\end{array}$ & $\begin{array}{c}\text { Armed } \\
\text { Forces }^{\mathrm{b}} \\
\text { (thousands) }\end{array}$ & $\begin{array}{l}\text { Manhours } \\
\text { Per Capita }^{c} \\
(1941=100)\end{array}$ & $\begin{array}{c}\text { Labor } \\
\text { Productivity }^{d} \\
(1941=100)\end{array}$ & $\begin{array}{c}\text { Real Wages in } \\
\text { Manufacturing } \\
\quad(1941=100)\end{array}$ \\
\hline 1938 & 40,718 & 323 & 88 & 89 & 88 \\
\hline 1939 & 42,139 & 334 & 91 & 92 & 89 \\
\hline 1940 & 43,874 & 458 & 93 & 95 & 90 \\
\hline 1941 & 47,349 & 1,801 & 100 & 100 & 100 \\
\hline 1942 & 49,885 & 3,859 & 107 & 100 & 112 \\
\hline 1943 & 50,656 & 9,045 & 109 & 102 & 124 \\
\hline 1944 & 49,513 & 11,452 & 106 & 108 & 128 \\
\hline 1945 & 47,994 & 12,123 & 99 & 114 & 128 \\
\hline
\end{tabular}

${ }^{\text {a}}$ Kendrick's measure of persons engaged as reported in Long Term Economic Growth (1973, p. 194).

${ }^{b}$ Armed forces from Historical Statistics of the U.S., U.S. Department of Commerce (1975, p. 1141).

'Kendrick's total private manhours as reported in Long Term Economic Growth (1973) divided by population over 16.

${ }^{\mathrm{d}}$ Kendrick's index of output per manhour as reported in Long Term Economic Growth (1973).

${ }^{\mathrm{e}}$ Real wages in manufacturing defined as the ratio of average hourly earnings in manufacturing from Historical Statistics of the U.S. (1975, p. 168) divided by the CPI all items same source, p. 211. 


\section{Table 3}

U.S. Total Factor Productivity During World War II

\begin{tabular}{lccc}
\hline \hline Subperiod & $\begin{array}{c}\text { Private Capital } \\
\text { (percent) }\end{array}$ & $\begin{array}{c}\text { Private Plus } \\
\text { GOPO Capital } \\
\text { (percent) }\end{array}$ & $\begin{array}{c}\text { Capacity } \\
\text { Utilization } \\
\text { (percent) }\end{array}$ \\
\hline $1938-1941$ & 4.3 & 4.3 & 3.7 \\
$1941-1944$ & 4.0 & 2.5 & 1.8 \\
$1944-1947$ & -1.2 & -1.0 & 0 \\
\hline \hline
\end{tabular}

${ }^{a}$ The figures in this table are average annual growth rates in total factor productivity. 
Table 4a. Correlations of Detrended Data for Great Britain, 1910-1965

\begin{tabular}{lcccccc}
\hline \hline & \multicolumn{3}{c}{ Cross-correlation with GDP $(\mathrm{t}+\mathrm{i})$} & \multicolumn{3}{c}{ Cross-Correlation with Mil $(\mathrm{t}+\mathrm{i})$} \\
\cline { 2 - 7 } & \multicolumn{1}{c}{-1} & \multicolumn{1}{c}{0} & \multicolumn{1}{c}{1} & \multicolumn{1}{c}{-1} & \multicolumn{1}{c}{0} \\
\hline GDP & 0.92 & 1.00 & 0.92 & 0.38 & 0.59 & 0.70 \\
C & 0.16 & 0.27 & 0.36 & -0.49 & -0.46 & -0.39 \\
I & -0.11 & -0.03 & 0.07 & -0.53 & -0.61 & -0.60 \\
Netx & -0.09 & -0.15 & -0.11 & -0.27 & -0.47 & -0.61 \\
Gov & 0.69 & 0.71 & 0.61 & 0.66 & 0.90 & 0.99 \\
Mil & 0.70 & 0.59 & 0.39 & 0.90 & 1.00 & 0.90 \\
G-EXP & 0.47 & 0.33 & 0.10 & 0.88 & 0.92 & 0.76 \\
G-REV & -0.16 & -0.38 & -0.54 & 0.59 & 0.37 & 0.12 \\
Emp-Civ & 0.14 & 0.18 & 0.28 & -0.27 & -0.29 & -0.17 \\
Emp-mil & 0.59 & 0.53 & 0.36 & 0.84 & 0.96 & 0.94 \\
GDP/Emp & 0.91 & 0.99 & 0.91 & 0.39 & 0.58 & 0.68 \\
Wage & -0.51 & -0.57 & -0.51 & -0.38 & -0.56 & -0.63 \\
RR-long & -0.49 & -0.58 & -0.55 & -0.34 & -0.56 & -0.66 \\
\hline \hline
\end{tabular}

Table 4b. Correlations of Detrended Data for U.S., 1910-1968

\begin{tabular}{lcccccc}
\hline \hline & \multicolumn{3}{c}{ Cross-correlation with GNP $(\mathrm{t}+\mathrm{i})$} & \multicolumn{3}{c}{ Cross-Correlation with Mil $(\mathrm{t}+\mathrm{i})$} \\
\cline { 2 - 7 } & \multicolumn{1}{c}{-1} & 0 & \multicolumn{1}{c}{1} & \multicolumn{1}{c}{-1} & \multicolumn{1}{c}{0} & \multicolumn{1}{c}{1} \\
\hline GNP & 0.88 & 1.00 & 0.88 & 0.65 & 0.73 & 0.68 \\
C & 0.62 & 0.58 & 0.47 & 0.05 & -0.04 & -0.12 \\
I & 0.47 & 0.44 & 0.40 & 0.02 & -0.11 & -0.15 \\
Netx & 0.03 & -0.12 & -0.06 & 0.05 & -0.20 & -0.25 \\
Gov & 0.51 & 0.66 & 0.59 & 0.67 & 0.89 & 0.89 \\
Mil & 0.67 & 0.73 & 0.66 & 0.90 & 1.00 & 0.90 \\
G-EXP & 0.40 & 0.48 & 0.42 & 0.82 & 0.91 & 0.81 \\
G-REV & 0.72 & 0.73 & 0.61 & 0.89 & 0.88 & 0.75 \\
H & 0.84 & 0.92 & 0.84 & 0.50 & 0.54 & 0.52 \\
N & 0.83 & 0.92 & 0.85 & 0.52 & 0.55 & 0.52 \\
Emp-mil & 0.66 & 0.75 & 0.68 & 0.86 & 0.98 & 0.93 \\
GNP/H & 0.77 & 0.90 & 0.77 & 0.69 & 0.81 & 0.74 \\
GNP/N & 0.53 & 0.64 & 0.49 & 0.56 & 0.72 & 0.67 \\
Wage & 0.31 & 0.27 & 0.12 & 0.04 & 0.09 & 0.05 \\
RR-short & -0.05 & -0.12 & -0.20 & -0.54 & -0.50 & -0.40 \\
RR-long & -0.17 & -0.24 & -0.32 & -0.57 & -0.53 & -0.43 \\
\hline \hline
\end{tabular}




\section{Table 5 .}

Conditional Means and Transition Probabilities for

Government Investment, Government Consumption, and Military Hours

\begin{tabular}{|c|c|c|c|c|c|c|c|}
\hline & \multicolumn{3}{|c|}{ United States } & \multicolumn{3}{|c|}{ United Kingdom } & \multirow[b]{2}{*}{$\pi^{\dagger}$} \\
\hline & $\mathrm{i}_{\mathrm{g}}$ & $\mathrm{b}_{\mathrm{g}}$ & $\mathrm{a}$ & $\mathrm{i}_{\mathrm{g}}$ & $b_{g}$ & $\mathrm{a}$ & \\
\hline 1 & 0 & .0762 & .0024 & .0010 & .0534 & .0057 & $\pi_{11}=.97, \pi_{12}=.03$ \\
\hline 2 & .0024 & .0751 & .0033 & .0024 & .0858 & .0069 & $\pi_{21}=.05, \pi_{22}=.20, \pi_{23}=.75$ \\
\hline 3 & .0153 & .0892 & .0121 & .0036 & .1705 & .0348 & $\pi_{33}=.25, \pi_{34}=.75$ \\
\hline 4 & .0401 & .1497 & .0241 & .0145 & .1853 & .0502 & $\pi_{44}=.25, \pi_{45}=.75$ \\
\hline 5 & .0406 & .1678 & .0510 & .0131 & .1830 & .0570 & $\pi_{55}=.25, \pi_{56}=.75$ \\
\hline 6 & .0235 & .1750 & .0626 & .0105 & .1850 & .0625 & $\pi_{66}=.25, \pi_{67}=.75$ \\
\hline 7 & .0177 & .1384 & .0674 & .0056 & .1635 & .0660 & $\pi_{17}=\underset{(.75)}{.9,} \pi_{77}=.1$ \\
\hline
\end{tabular}

${ }^{\dagger}$ All of the transition probabilities for the U.S. and Great Britain are the same except for state 7 where the British probabilities are in parenthesis. 
Table 6

Hours and Productivity for Model Simulations of World War II ${ }^{\dagger}$

\begin{tabular}{cccccc}
\hline \hline & \multicolumn{2}{c}{ United States } & & \multicolumn{2}{c}{ United Kingdom } \\
\cline { 2 - 3 } \cline { 5 - 6 } Year & $\begin{array}{c}\text { Hours } \\
(1941=100)\end{array}$ & $\begin{array}{c}\text { Labor } \\
\text { Productivity } \\
(1941=100)\end{array}$ & & $\begin{array}{c}\text { Hours } \\
(1938=100)\end{array}$ & $\begin{array}{c}\text { Labor } \\
\text { Productivity } \\
(1938=100)\end{array}$ \\
\hline 1938 & 91 & 95 & & 100 & 100 \\
1939 & 91 & 97 & & 121 & 97 \\
1940 & 99 & 97 & & 119 & 101 \\
1941 & 100 & 100 & & 114 & 104 \\
1942 & 100 & 103 & & 110 & 106 \\
1943 & 94 & 106 & & 105 & 108 \\
1944 & 90 & 108 & & 99 & 111 \\
1945 & 85 & 110 & & 102 & 110 \\
\hline \hline
\end{tabular}

${ }^{\dagger}$ Note that we have added $2 \%$ annual growth to labor productivity to facilitate comparison with Tables 1 and 2. 
Figure 1: Government investment, government consumption and conscription during World War II.
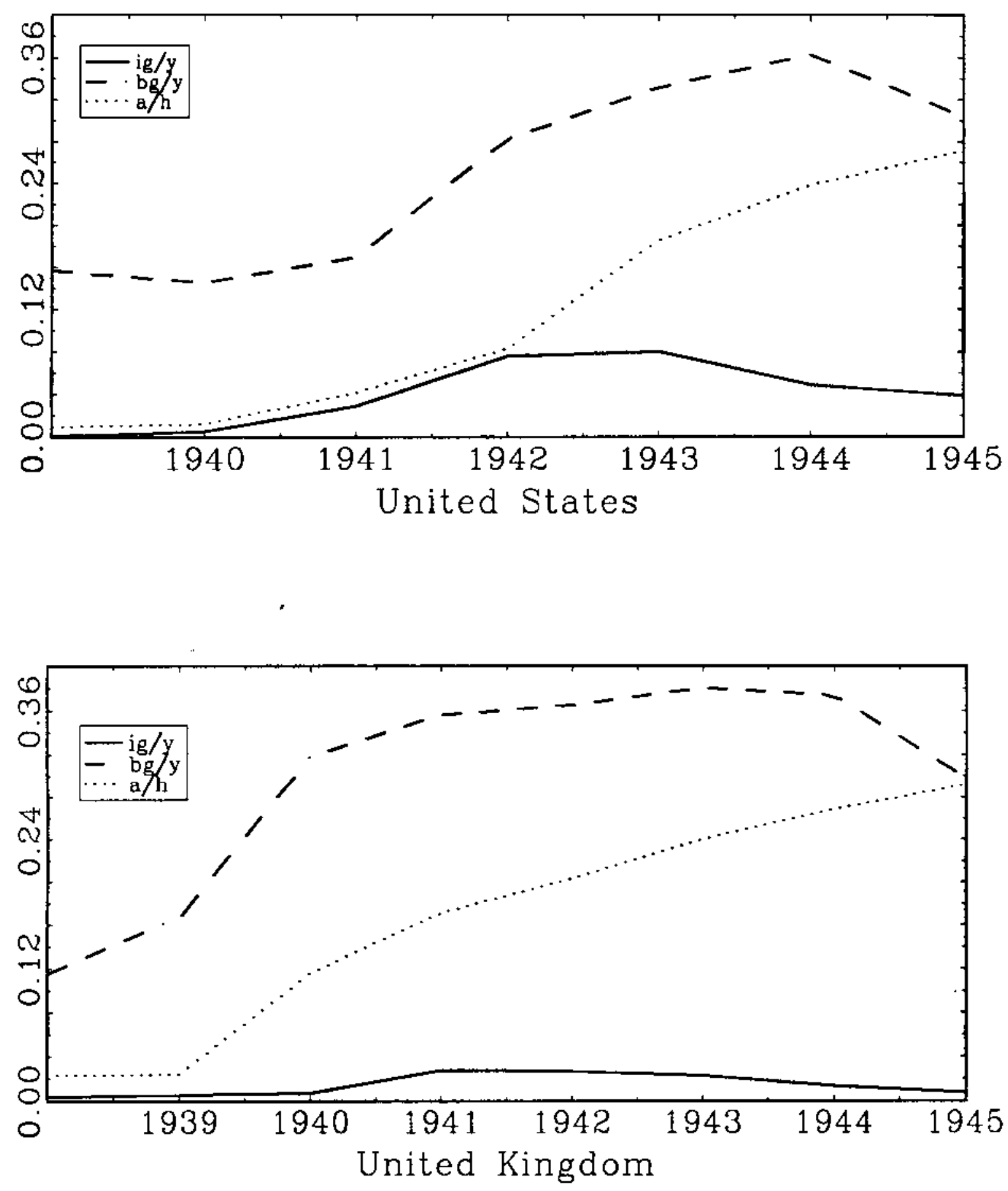
Figure 2: privately owned capital and government-owned privately-operated capital

in manufacturing

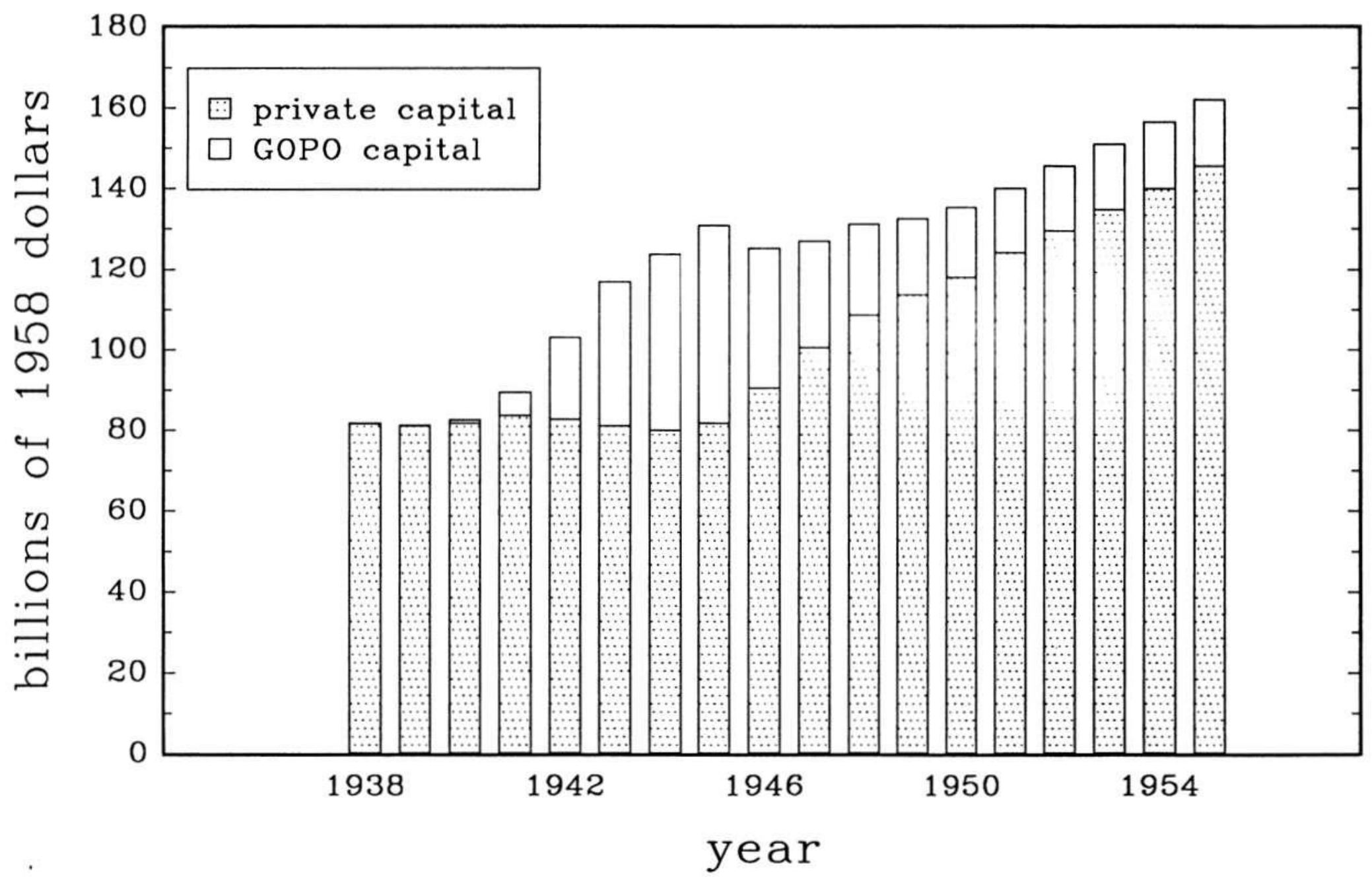


Figure 3: Government investment, government consumption and conscription during World War II.
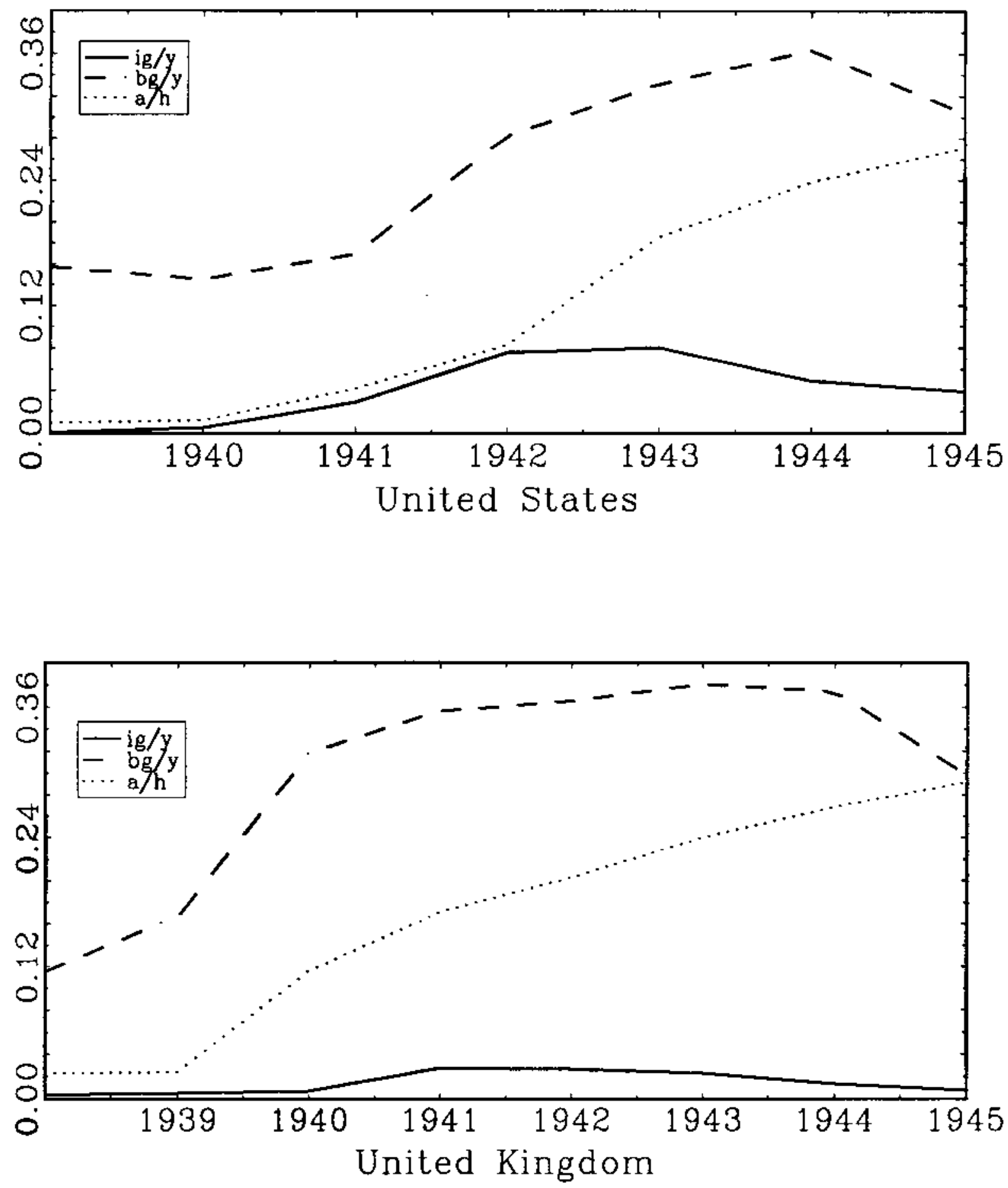
Figure 4: Simulated and actual changes in the composition of output
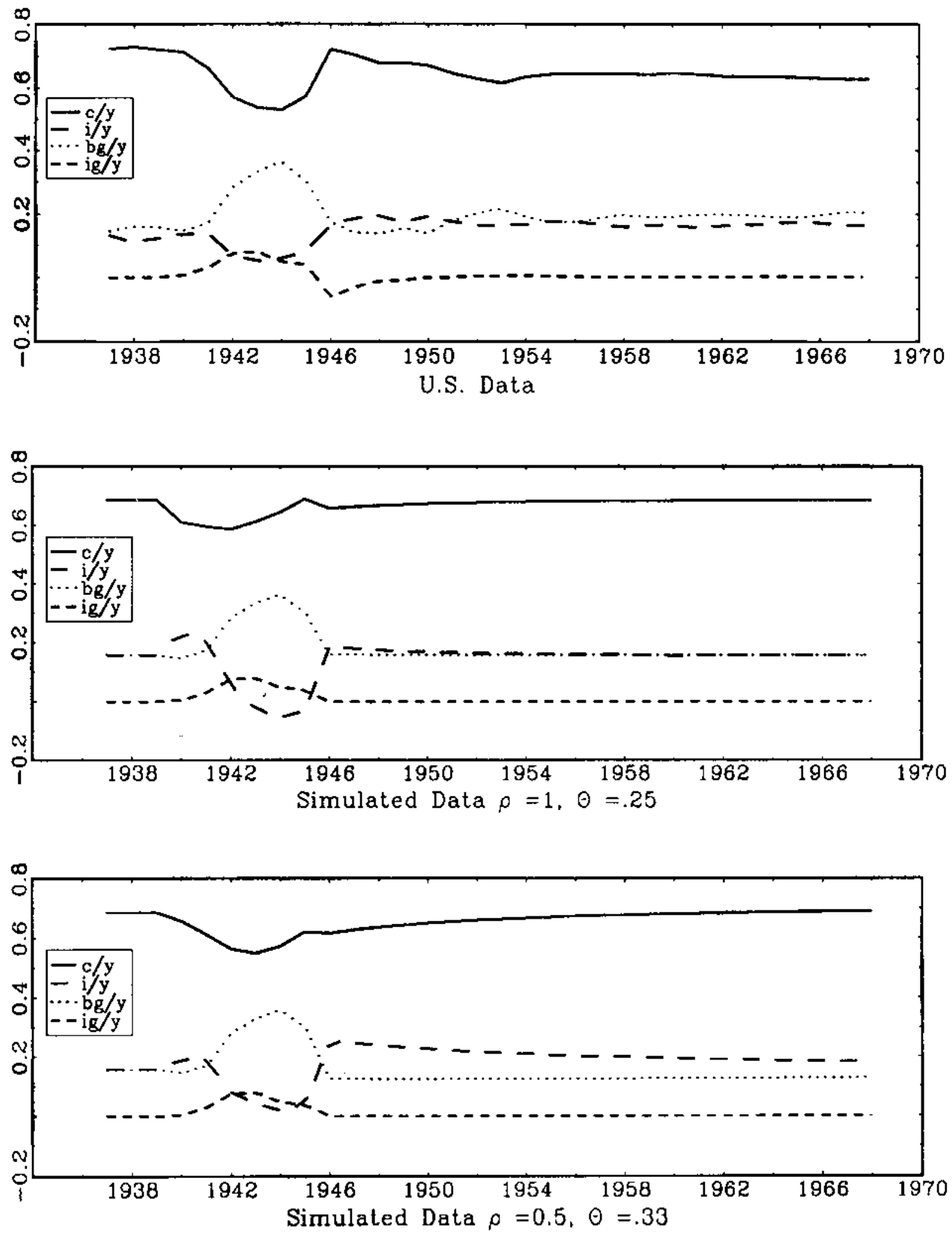